\title{
A CHARTER FOR THE
}

SOCIAL SCIENCES

CHARIES A, BEARD

DARTI: REPOR' OF THE COMMISSION

ON THE SOCIAL STUDIES

AMEIICAN HISTORICAL ASSOCIATION 
From the collection of the

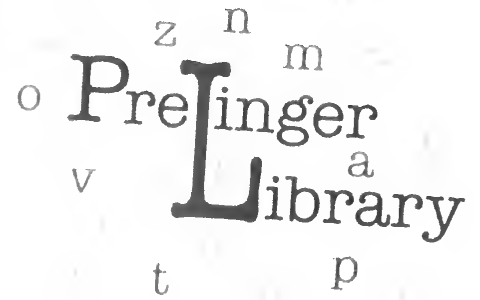

San Francisco, California 2006 




A CHARTER

FOR THE SOCIAL SCIENCES

IN THE SCHOOLS 


\section{AMERICAN \\ HISTORICAL ASSOCIATION}

INVESTIGATION OF THE

SOCIAL STUDIES IN THE SCHOOLS

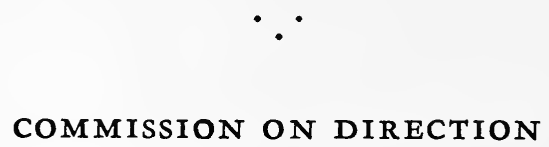

A. C. KREY, Chairman

FRANK W. BALLOU

CHARLES A. BEARD

ISAIAH BOWMAN

ADA COMSTOCK

GEORGE S. COUNTS

AVERY O. CRAVEN

EDMUND E. DAY
GUY STANTON FORD

CARLETON J. H. HAYES

ERNEST HORN

HENRY JOHNSON

LEON C. MARSHALL

CHARLES E. MERRIAM

JESSE H. NEWLON

JESSE F. STEINER 
REPORT OF THE COMMISSION ON THE SOCIAL STUDIES

$$
P A R T I
$$

\section{A CHARTER}

FOR THE SOCIAL SCIENCES

\section{IN THE SCHOOLS}

DRAFTED BY

Charles A. Beard

CHARLES SCRIBNER'S SONS NEW YORK CHICAGO BOSTON ATLANTA SAN FRANCISCO DALLAS 


\section{COPYRIGHT, 1932, BY}

\section{CHARLES SCRIBNER'S SONS}

Printed in the United States of America

All rights reserved. No part of this book may be reproduced in any form without the permission of Charles Scribner's Sons

A

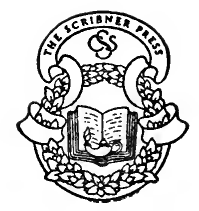




\section{PREFACE \\ H 6? 455}

This charter of the social sciences, like many another document, is itself the product of history and of the social forces that shaped the thinking of the individuals who sign it. They have drawn upon their own age and upon the past in this effort to open up for teachers and for thoughtful men and women in every walk of life the prospect of an educational approach to an understanding of the world today and of the forces with which youth must reckon when it attempts to shape the world of tomorrow.

The chain of events which led to this investigation and the appointment of the present Commission to direct it is a long one and composed of many links. The detailed account of the progress of this study, and the list of distinguished scholars, educational administrators, men in public life, as well as class-room teachers, who were called upon to aid the Commission on one or several phases of its problem will more properly preface the volume of conclusions with which this investigation is to 


\section{Preface}

end its work in December, 1933. It must suffice here to summarize briefly the events which led to the appointment of the Commission and the formulation of this Charter.

The Charter is in a sense its own explanation. The careful reader will find both expressed and implied in it the conviction on the part of educators and social statesmen that there is need of wise readjustment in our thinking and our educational program to a world that has become urbanized, mechanized, and interlocked in its social, economic, political, and cultural interests. It is a tribute to the high sense of public responsibility held by educators and scholars in the social sciences that they were neither unconcerned about, nor indifferent to, the educational implications of these changes. As individuals, as local groups, and as national associations, they attacked the problem of curricular readjustment. By I922, nearly all of the great national associations had published committee reports suggesting more or less extensive remedial measures.

An exploratory survey of the teaching of the social sciences in the schools during the year 1923-24 


\section{Preface}

underlined the need for constructive leadership. The report of this committee ${ }^{1}$ described the curricula of social studies over the country as in a state of "chaos." Teachers and school administrators, forced to meet the immediate and daily demands of constantly increasing numbers of pupils as well as of changing social conditions, were reaching out for guidance. They were drawing from the several separate reports in varying combination and finding none of them adequate. In this uncertainty, the days, when the reports of the Committee of Seven for the Secondary School and of the Committee of Eight for the Elementary School served as a common standard, seemed like a golden age to the harassed administrators and teachers.

Such guidance as the school authorities and teachers desired, however, could only be afforded through the most cordial co-operation of all the groups most directly concerned in the problem. The Council of the American Historical Association which had sponsored both the Committee of Seven and the Committee of Eight was now asked to sponsor this undertaking. The Council ${ }^{1}$ Dawson, Edgar: The History Inquiry, McKinley Pub. Co., Phila., 1924. 


\section{Preface}

appointed a committee to investigate the possibility of such a study. The report of this committee, in 1925, emphasized the three elements of extensive co-operation, intensive study and adequate resources as essential and briefly outlined some of the details. The cost of this undertaking was beyond the means of the Association. The authorities of the Commonwealth Fund expressed an interest in the proposal and appropriated a sum to cover the preparation of a definite plan for such an investigation. A planning committee was appointed composed of Messrs. John S. Bassett, Guy Stanton Ford, Ernest Horn, Henry Johnson, William E. Lingelbach, L. C. Marshall, C. E. Merriam, Jesse H. Newlon, with A. C. Krey, Chairman. This committee drafted a plan which was presented to the Council in December, 1926, and approved by that body.

In the fall of 1927 the Carnegie Corporation made an appropriation to permit the recasting of this plan into "working drawings." At the annual meeting of the American Historical Association, held in Washington, D. C., December, 1928, it was announced that the Carnegie Corporation had viii 


\section{Preface}

appropriated the funds necessary to undertake the investigation. The Council at the same time nominated the personnel of the Commission to direct this investigation. This Commission began its work in January, 1929. During its first year, the Commission had the assistance of Messrs. Evarts B. Greene and William E. Lingelbach. When other demands of the Association made it impossible for them to continue this work, Messrs. Avery O. Craven and Carleton J. H. Hayes were called upon to fill their places. With these exceptions, the personnel of the Commission has remained unchanged throughout this investigation.

The first task of the Commission when it began its work in 1929 was a consideration of objectives. Fortunately the membership of the Commission included some who had taken part in the deliberations of earlier committees of the several associations engaged on this problem. The Commission as a whole reflected a very wide range in points of view which the discussion of objectives had developed. There was, therefore, no easy ready-made solution which they could, or would, adopt. After prolonged discussion of this problem, the Com- 


\section{Preface}

mission decided to appoint a sub-committee to continue consideration of objectives. To the five members of the Commission-Messrs. Beard, Counts, Ford, Krey and Merriam-it added Messrs. Franklin A. Bobbitt, Boyd H. Bode and Harold O. Rugg, each of whom had developed a distinctive approach to the problem of objectives in education. This committee worked at its task over a period of nearly two years. It met with the Commission at Briarcliff and at Asheville and held two separate meetings at Chicago and at New York. It met once with the Committee on Tests at New York. Each of the members had an opportunity to present his views of the problem in writing as well as orally. Finally, the committee instructed Mr. Beard to draft a report embodying its collective views. This report was submitted for the consideration of the Commission at Briarcliff, October 15, 1930. Every member of the Commission was called upon to comment upon the report and did so. The discussion continued over two days and the committee was instructed to prepare a revised statement. This was done, and the revised statement was presented to the Commission 


\section{Preface}

at Washington, May 7, 1931. Again each member of the Commission was called upon for comment. At the conclusion of the discussion a motion to approve the report was made and carried unanimously.

This brief recital of the steps which have led to the formulation of this statement can only faintly suggest the thought and effort which it has involved. Every member of the committee and practically every member of the Commission contributed to its composition. The staff of the investigation analyzed courses of study and text-books and made summaries of the more extended pedagogical writings. All this material as well as the oral discussion, which was preserved in stenographic form, was drawn upon in the composition of the final report. Those who followed the discussion closely would have little difficulty in identifying the individual contributions. To Mr. Beard was given the task of gathering from the accumulated mass of written and oral material all the essential contributions and weaving them together into a coherent whole.

In printing this statement at this time, the Com- 


\section{Preface}

mission hopes to enlist the criticism and suggestions of a wider audience. The other activities of the investigation are expected to furnish help in translating this statement into practical ways and means for meeting the needs of successive school grades. Arrangements have been made with the publishers to issue the successive parts of the Commission's report as these are prepared. Any necessary modifications of the charter suggested by the other findings of the investigation or the criticisms of the wider audience can be incorporated in the volume of conclusions with which the Commission will end its work in December, I933.

A. C. KReY, Chairman. 
A CHARTER

FOR THE SOCIAL SCIENCES

IN THE SCHOOLS 



\section{A Charter for the Social Sciences in the Schools}

Such is the unity of all things that the first sentence on instruction in the social studies in the schools strikes into a seamless web too large for any human eye. ${ }^{1}$ Whether we consider the intrinsic nature of the various realities included under the head of social science, or the results that flow from the interpretation of them in the schools, or their place in the unfolding of history, we are in the presence of universality far beyond our grasp. This alone should give pause to those who fain would rush into the discussion of the issues before us with logical schemes, mild prophylactics, or final panaceas. After assembled wisdom has said its last word, the still small voice of discovery will be heard in unexpected and unofficial quarters, and new planets will swing within the ken of watchers. But while we must remain to the end keenly aware of limits on our grasp, we

1 This beautiful symbol is borrowed from the opening sentence to the Introduction to the History of English Law by Pollock and Maitland. 


\section{$A$ Charter for the Social Sciences}

may attempt to strike into the task somewhere near the center; or, to speak more modestly, we may begin by frankly setting up bench marks in the form of declarations of fact or material assumptions to serve as points of reference for our explorations.

Speaking generally, we may say at the outset that instruction in social studies in the schools is conditioned by the spirit and letter of scholarship, by the realities and ideas of the society in which it is carried on, and by the nature and limitations of the teaching and learning process at the various grade levels across which it is distributed. Admittedly, other stipulations are possible, but these seem to be stubborn and irreducible, to use favorite words of William James. They seem to set a certain inevitable framework for determining the content and applications of civic instruction. So much, therefore, we assume in the beginning.

Scholarship has its own imperatives. To say that science exists merely to serve the instant need of things, causes, or parties is to betray a fatal ignorance of inexorable movements in 


\section{$A$ Charter for the Social Sciences}

thought. Equally objectionable is the conclusion that in the selection, organization, and presentation of materials, science can ignore the requirements and demands of the society which sustains it, the society in which it flourishes-the requirements and demands of a world actually wrestling with problems and insisting upon answers, provisional, perhaps, but still answers of the highest conceivable validity. If somewhere in a land of utopia there could be effected among adults a perfect reconciliation between ever exploring social science and the immediate demands of the social order, still instruction in humanistic subjects in the schools would have to be refashioned at each grade level on the basis of widening horizons of thought. The necessities of scholarship, the realities of society, and the requirements of the teaching and learning process-these form inescapable covenants binding upon this Commission. The structure of ideas thus established seems to be more than a mere confession of faith; it appears to be so indubitable as to call for no justification, although we are far from thinking that it is simple in its nature and implications. 
$A$ Charter for the Social Sciences

THE REQUIREMENTS OF SCHOLARSHIP

For a number of reasons it is fitting to open with the requirements of scholarship. Above all it must be remembered that we speak for a fellowship of scholars gathered under the auspices of the American Historical Association and unofficially for their colleagues in other disciplines. To be sure, we are well aware of our obligations as citizens and we believe that in the deepest sense the disinterested pursuit of truth and the permanent interests of society are not incompatible; indeed, such a paradox would be almost unthinkable; but it is the American Historical Association, not the Congress of the United States, which has created and instructed this Commission. Hence we are compelled to operate over a wide philosophical range-the range set by the span of universal history.

There is another, and perhaps more exigent, reason for placing the requirements of scholarship at the opening of this report. If truth is not easy to discover, if it is not always mighty, and often seems to fail rather than prevail, yet it has always 


\section{Requirements of Scholarship}

been and still is the goal toward which the world's greatest thinkers have resolutely set their faces. To scholarship no other goal seems possible. Again and again in history, the truth rides over the set conventions of society. Society may say in a voice of thunder that the earth is flat and is immovable and may concentrate all the engines of authority on crushing those who believe otherwise; but the revelations of astronomy are not destroyed. Defeated in life, Galileo triumphs in death. Scholars must deal with ideas, facts, and opinions as stubborn as those which society imagines to be the ascendant realities of the present, and they must report what they find or keep silence.

When the historian works at the life of Cæsar or Cromwell, or Mary Wollstonecraft or Lincoln, he cannot be dominated by haunting fears as to the possible applications of his findings to practical affairs. When the economist delves deeply into price fluctuations, he cannot keep his eyes at the same time on the stock ticker if he is to do his duty to his science. The sociologist studying the history of matrimonial institutions 


\section{$A$ Charter for the Social Sciences}

will not find truth if he is constantly worried about the possible upshot of every discovery. Pure scholarship, of course, is a matter of degree rather than absolutes, but it is an ideal which must be kept before us. Without the results which flow from the disinterested quest of truth for its own sake, the social practitioner could scarcely rise above the plane of the astrologer.

No more than society itself must scholars justify themselves. They stand where they stand and they have their reason of faith, if not of State. By the vows of their craft, they must cover the wide world and all time with their searchings. Nothing that mankind has done on the face of the earth is foreign to their interest. They use all the great languages living and dead in their researches. They delve amid the ruins of the buried empires of antiquity in their quest for more light on the origins of civilization. They visit the newest industrial cities hunting light on social organization. Ur of Chaldee and "Middletown," U. S. A., are properly subjects for their investigation and meditation. All forms of government, no less than the Constitution of the United States, all religions, 
all economic orders, all crafts and all arts, the noblest aspirations of humanity and the crimes of opinion and violence fall within the reach of their study and contemplation. Nature and natural science in their manifold aspects are not alien to them, for mankind works with material instruments within geographical settings. A material scaffolding as well as accumulation of ideas accompanies the rise of civilization from primitive barbarism and cannot be ignored by those who would understand the past as it was and the present as it is-foreshadowing always a future eternally in the process of becoming.

In short, under the wide dome of universality, these scholars carry on their unceasing labors, changing from day to day our knowledge of the world and its records, giving new aspects to the oldest antiquities and the latest of inventions. To be sure, none of us is strong enough to gather the fruits of their researches into one mighty synthesis, to construct a scheme of ideas proportionately and artistically mirroring the total reality which they are seeking to describe; but all who rise above the barest routine must take thought of 
that responsibility. In fact, out of the immense and perplexing diversities which specialists unearth are arising dim and fragmentary pictures of the whole, like some of Rodin's statues, never to be perfect and yet forever seeking perfection-the impossible.

By the vows of their craft, imposed by the very nature of the mind and the materials in which they delve, these scholars are committed to a method indispensable to their cause. Wherever they labor they must have before them one object -the truth about the matter undes inquiry, whether small or great. If that is not their goal, what other alternative is possible? And if their method is to be characterized by a single constricting adjective, it must be the word "scientific." About the inner essence and ultimate validity of the scientific method, especially its relation to logic and imagination, much can be said by way of criticism. Around its outer edges, as of all other instrumentalities of inquiry and thought, hovers uncertainty; but the rational exigency of its demands cannot be denied. Those who follow it say, in effect, "give us all the pertinent facts 


\section{Requirements of Scholarship}

available about the situation in hand, accurately and precisely disengaged from rumor and mythology; let us assemble and arrange them with primary reference to their inner necessities; let us view them with calm detachment, eliminating as far as humanly possible all our immediate interests and preconceptions; let the ordered facts speak for themselves to those who have ears to hear, trusting the event to a power beyond ourselves."

Such in summary is the method employed with more or less success by the society of scholars for whom we speak. They apply it with the same rigor to the most remote affairs and those nearest at hand-to the fall of the Sung dynasty, the dissolution of the Persian empire, the overthrow of Napoleon, the end of the Romanoffs, and the forces determining the selling value of wheat on the world market. They cannot shrink from applying it in the comparative study of religionsthe teachings of Buddha, Confucius, Jesus, and Mahomet, or the primitive mythology of Samoan Islands. Where are the oldest and most authentic texts? How do we know that they are correctly 


\section{A Charter for the Social Sciences}

representative? What does philology say about their true interpretation? Such are the questions which scholars must ask when they approach any theme of historical significance. Can they do otherwise? If so, what is the alternative?

In the same spirit they must study the great movements and crises of history which have shaken established orders to their foundation. The Puritan Revolution in England, the American Revolution, the French Revolution, the Russian Revolution-all these upheavals are to be examined with the same control over emotions which the geologist exercises when he traces the transformations registered in the great book of nature. Inevitably, therefore, the scholar is bound to apply to each situation he examines-and to the total situation if he dares to approach it-all the engines of verification and criticism that he can command. By choosing any other method, he would fall short of his whole duty in the premises.

Since this is so, he is likely on various occasions to run counter to what John Morley calls "accepted maxims," or "those sentiments or current precepts of morals which may in truth be 
very equivocal and may be much neglected in practice, but which the public opinion of his time requires to be treated in theory and in literature as if they had been cherished and held sacred semper, ubique, et ab omnibus." Is it conceivable that one who has devoted years to a subject can come out at the end with the views and theories entertained respecting it by the person who has given no special attention to the matter, but is content with what his tradition dictates to him? If scholarship ends where ignorance begins, it can hardly be justified as a pursuit for intelligent men and women. It is scarcely possible that even the witless would hold a brief for any other conclusion on this point. Hence it must be admitted that the scientific method applied to human affairs is likely to run counter to neat little conceptions adapted to popular consumption and pleasure.

Yet in applying it, the scholar is aware of its limitations. He knows that it is workable only in "the narrow land of rational certainty, relative, conditional, experimental." He has seen so many discredited theories and convictions scattered along the path of humanity that he is forever on 


\section{$A$ Charter for the Social Sciences}

guard against resorting to case-hardened dogmas in his own field. In his sober moments he suspects with Carlyle that "the course of Nature's phases on this our little fraction of a Planet is partially known to us; but who knows what deeper courses they depend on-what infinitely larger cycle [of causes] our little Epicycle revolves on?"

Out of all this comes a curious paradox; the scientific method of scholarship, which applies the Socratic elenchus to "accepted maxims," shrinks from attempting to devise a new maxim for every vacuum created by research. If Bismarck looked on scholarship as chiefly useful in supplying good excuses for things done or in the process of doing, other practical men of affairs have been prone to regard it as a frail justification for timidity. Still it may happen that the light of the scholar's study will shine longer and brighter than the hot passions that burn in the forum. In any event, this Commission, representing a republic of letters and reflecting its ideals, is bound to give full recognition to its methods and its spirit in considering what objectives are possible in the social studies supplied for the schools. 


\section{Nature of Social Disciplines}

THE NATURE OF THE SOCIAL DISCIPLINES

If in framing a program of social studies we are bound to take into reckoning the spirit and methods of the scholarship which furnishes the materials, we are likewise under the necessity of penetrating as near as we can to the heart of the social studies themselves-the vast body of literature dealing with human affairs. What, after all, is social science? It seems impossible to answer this question categorically, for all the philosophies of the world have failed to bring the several social disciplines into an ordered picture. But can we set up a scheme of instruction in a series of subjects without first taking thought about their intrinsic nature and intimate unity? That, too, seems impossible.

When we examine closely the huge body of literature coming under the head of social studies, including at least several thousand of the central pieces, we find that it is a curious combination of materials. By no possible legerdemain can it be cut, reduced, and fitted into a form that can be easily presented even to mature minds, to say 


\section{$A$ Charter for the Social Sciences}

nothing of children in the grade schools. To be sure there are many texts in history, economics, civics, sociology, and kindred subjects which, taken collectively, are advertised as "covering the whole field." In a way, more or less satisfactory, they do, of course; but no philosopher could accept them as more than the beginning of a tale to be told. If, on the other hand, we direct our attention to the great works in this field from which all others are drawn, we find no such neatness in detail, or grave perfection in the mosaic.

The literature of social studies is a blend of many intellectual strains. Some of it is microscopic in character-commodity prices in a single locality over a period of years, the operation of the zoning law in a single city, a critical edition of the Senatus consultum de controversia inter publicanes et Pergamenos, or Buddhist texts of a monastery in Japan. Other pieces represent creative work of the highest order, done with great philosophic thoroughness-Adam Smith's Wealth of Nations, Ranke's History of the Popes, or Sombart's Der moderne Kapitalismus.

Defense mechanisms or rationalizations of given 


\section{Nature of Social Disciplines}

orders of society abound; in fact, they are so well known that illustrations are unnecessary. Within this class falls Treitschke's great treatise on Politics. A very large part of the work in social sciences is purely ideological in nature and purpose. Akin to this type is a large body of literature criticizing given arrangements and advocating changes in them, more or less revolutionary; the Federalist, written in support of the Constitution of the United States, one of the great books of all time, comes fairly within this category.

Again a book in political science emphasizes one or another aspect of human development and forwards tendencies well under way; for example, Rousseau's Social Contract, the handbook of the French Revolution, or Marx's Das Kapital, the Bible of socialism. Standing sometimes independently and at other times running through numerous branches of thought is utopian idealismgreat dreams for mankind never yet realized: Plato's Republic, or More's Utopia. Finally, there is a mountain of books written to satisfy a limited curiosity, to keep alive tradition in story and song, or to make a display of learning as the justifica- 


\section{$A$ Charter for the Social Sciences}

tion for holding a paid job, or as an expression of feeble intellectual capacities. Occasionally there is a writer bold enough to attempt to grasp destiny by the forelock and bring it down for our examination: Hegel's Philosophy of History or Spengler's Decline of the West.

It is out of this vast complex of ideas, observations, accumulations, and inferences, supplemented by personal inquiries and experience, that our little schemes of social studies must be manufactured. Should the task appear discouraging, then we have to face the more serious alternative of giving no thought to the subject whatever. Here, as in many other ways of life, it is not a mere condition or a theory that confronts us, but a paradox!

Out of the raw materials of the world and life, out of the immense accumulation of ideas and traditions incorporated in the written word, must be made the social science to be taught in the schools and the purposes governing its presentation. And by whom are the programs and methods for the schools formulated? By individuals and groups possessing given cultural in- 


\section{Nature of Social Disciplines}

heritances and operating within the limits of an intellectual climate, narrow or broad to universal, according to circumstances. They are not infallible but are themselves a part of the drift they seek to describe. The worlds of fact and opinion, parts of the same thing, reflecting perhaps some deeper underlying reality, evolve together. The late war in Europe, for instance, partly the outcome of ideas, was a fact which in turn created a vast crop of ideas.

Of necessity, those who formulate programs are specialists in particular fields-one-sided persons. This cannot be avoided either. Under the stress of modern specialization, itself the inevitable result of intense efforts to see things more accurately and vividly, social science tends in practice to break up into disciplines, such as economics, politics, anthropology, psychology, sociology, geography, esthetics, ethics, imaginative literature, and history, each with an emphasis on selected aspects of human affairs.

Economics is primarily concerned with the production and distribution of wealth-their laws within certain political and cultural settings. Poli- 


\section{$A$ Charter for the Social Sciences}

tics selects for observation government in its manifold relations to all phases of human life, including individual liberty. Anthropology opens the way of our cultural evolution back through tangled years to the most primitive ages of which records can be obtained. Psychology is busy with mental processes and their outward manifestations. Sociology lays stress upon human associations, their internal forms and outward connections. Geography takes in the whole material theater in which the drama of nations is played. Esthetics considers the sublime and the beautiful, their origins and uses in the development of joy and admiration. Ethics concentrates on manners and customs and the choices of mankind in the unfolding of the good life. Imaginative literature reflects and etches in manifold pictures all the flashing facets of human conduct. At the center of each of these disciplines is a core of substantial data and inference; on the periphery lies an uncertain borderland where all merge in a transcendent interest. Each contributes to our insight into the world of fact and opinion in which we live and work.

Crowning them all is history, which began 


\section{Nature of Social Disciplines}

with the songs of bards and ends in philosophy. By taking for its data all that has been done and said on this earth since time began, history furnishes substance for philosophy and, in assuming an ordered form and progression, history becomes a philosophy, avowed or unavowed. For whatever principle of selection is applied in any historical scheme, it carries with it philosophic implications. There are, to be sure, specialized histories of economics, politics, and military affairs, but like the separate disciplines of contemporary life, they are for the sake of convenience and do not represent absolute divisions. Written history seeks to organize world affairs in their chronological chain according to their inner connections. It attempts to explain, within limits, how things came to be what they are by throwing them into perspective and sequential, if not causal, relations.

Perhaps a word of caution is necessary. This is not intended to imply that there is any such thing as a "philosophy of history," a transcendentalism to be derived from the study of events, but merely that history supplies data for philosophy and, whenever it is broadly conditioned, carries with it 


\section{A Charter for the Social Sciences}

in the selection, arrangement and statement of facts philosophic implications of the most inescapable sort. Metaphysics, says William James in effect, is what you have when you think hard enough about any subject. Philosophy is what the historian discovers when he stops adding pieces together and inquires how and why things happened and how and why he is arranging his report. So conceived, history can furnish cement to bind all other social disciplines into a workable unity, giving to them a patterned background and, by virtue of its basic time element, a dynamic which pertains to the future.

In this brief consideration of the several social disciplines it is far from our purpose to emphasize what has been called "the conventional boundaries" between them. Indeed, by thoughtful scholars in the several domains, even the most exacting specialists, these boundaries have never been treated as rigid, and during the past fifteen or twenty years there has been a marked tendency to cut across them in every direction. This does not mean, however, that $a$ or the social science has been created, a synthesis transcending the disci- 


\section{Requirements of Social Realities}

plines themselves. Nor in the present state of things does such an achievement seem possible. Each of the disciplines inevitably has a center of gravity or furnishes a point of view from which materials are surveyed and brought into an organization of knowledge. Apparently a synthesis, could it be effected, would be a skillfully wrought mosaic rather than subliminal coalescence in which the separate disciplines would disappear and completely lose their identity as law, politics, economics, geography, and history. Conceivably some higher unity may be attained, many new arrangements of materials may be effected, but the stubborn and irreducible elements of the special disciplines would remain imbedded in it and, unless it were formless and void, it would inevitably be organized around some central philosophy of concept, faith, or assertion.

REQUIREMENTS SET BY THE SOCIAL REALITIES OF OUR TIMES

Whatever may be the conclusions of pure scholarship on matters of detail, whatever canons of faith may be derived from the data and infer- 


\section{$A$ Charter for the Social Sciences}

ences of the several disciplines composing social science, they do not and cannot automatically provide all the substance and direction required for instruction in the social studies in the schools. We live not by the written word alone; nor derive from it all guidance in theory and conduct. The world of fact, opinion, and tradition lives about us endlessly, supplying materials and ideas which impinge upon all of us, teachers, pupils, and parents-from which we derive beliefs, convictions, satisfactions, and impulses to action. The industry described by the economist flourishes in the city in which his book is studied. The government which the political scientist analyzes into its parts surrounds and bears upon the students who read his pages. In the midst of a family explained by the sociologist, in its historical and practical setting, nearly every pupil who scans the printed lines lives more hours every day than he spends in the classroom. And a myriad vestiges of the historian's past stand out like half-submerged crags above the flood of the living present. The geologists' vast book of nature lies open before those who have eyes to see. Masters of social science are 


\section{Requirements of Social Realities}

not keepers of Delphic mysteries forever closed to the vulgar; many of the raw materials with which they work are open to all and are the objects of experience, if not contemplation, for those whom they teach. Moreover they themselves are not disembodied spirits but creatures of time and circumstance, wide or narrow, of the same clay as their pupils.

From what has been said about the nature of social science and the realistic world in which it must be formulated and taught, it follows that if a scheme of instruction were drawn solely from books it would not be good always and everywhere or produce identical results throughout the country. The divisions of the science are themselves in process of evolution in the very medium of fact with which they are entangled. Ideas drawn from them, no matter how fixed, cannot arbitrarily impose patterns of conviction and conduct on pupils without reference to what is actually taking place in society around them or to changes induced by facts-science, invention, industrial expansion, alterations in the prevailing modes of producing and distributing wealth. In- 


\section{$A$ Charter for the Social Sciences}

deed, attempts to impose stereotyped patterns of conviction and conduct often produce exactly the opposite of the purpose intended. Skepticism is frequently the fruit of over-emphasis on unquestioning belief-attempts to put precise limitations on life, which, as a growth, breaks bonds. Rigid preconceptions can only be successfully imposed and maintained in a society that is rigid; rigidity in intellectual life accompanies rigidity in economic life. With ruthless might new facts upset the fair pageantry of eternal schemes: Jefferson's America of free and upstanding farmers ruling the country in liberty has been turned upside down by steam and machinery. Ten million teachers singing the praises of agriculture would have been powerless to block that inexorable march; they might have put a drag on it, but no insurmountable barrier in its way.

A realistic program of social studies cannot be drawn with mathematical precision, therefore, from the realm of scholarly ideas without reference to actuality - to the prosaic world as a going concern. Of course, any scheme of human relations ranging from despotism to anarchy can be 
formulated on paper from the deliveries of social science, but at best it is likely to be utopian in character. Yet, to ignore ideas in shaping civic conduct is to court disaster, for they have a way of playing havoc with the best laid schemes for practical affairs; the humblest Christian workman in pagan Rome of the first century came nearer guessing the future (God's Providence) than the noblest Roman senator; William Lloyd Garrison, a fanatical agitator in Boston, was closer to the verdict of history than John C. Calhoun, the most logical and intelligent defender of slavery in the South. On the other hand, over-reliance on ideas has been responsible for the failure of a hundred paper constitutions drawn up for the government of sections of mankind. Ideas may be wasted as the billions of seeds tossed by nature to the winds; they may be destructive, leading to delusions and folly. They seem to be potent only when they fit, with some mysterious exactness, into the actuality of things in the process of development, now slowly altering great intellectual patterns by steady accumulation and now effecting fateful decisions in time of a crisis when a little push 


\section{$A$ Charter for the Social Sciences}

here or there appears to give a new course to human affairs.

If the foregoing assumptions are sound, then our program must be drawn from many quarters-from the several divisions of social science themselves, from the determinations of educators and writers who have sought, with more or less philosophic comprehension, to formulate schemes of instruction, and from what seems to be inevitable realities in American society as a part of a world fellowship of nations. It is not a question of potters and clay. A large part of our task is cut out for us by the nature of things, the resolutions of teachers' associations, and even the statutes of state legislatures. We may, of course, set up an ideal arrangement that will be pleasing to ourselves and our sense of logical perfection. We may, on the other hand, accept with Oriental resignation the thought that everything has been determined from the beginning and that the business of social science is to prepare individuals and nations for their fate. But it seems the better part of wisdom to assume that within practical limits choices may be made, ideals may be given con- 


\section{Requirements of Social Realities}

crete form, and dreams may be realized. Otherwise we are condemned to wander sightless in the gray wastes of destiny.

First among the conditioning realities which must shape our program of civic instruction is the changing nature of the society in which we live and work. We may greet this truth with an uncritical enthusiasm that welcomes every alteration as a step in beneficent "progress" or we may deplore it as ruinous to some utopian order of excellence existing somewhere in the past; but we cannot ignore it. It is another one of the stubborn and irreducible facts with which we must reckon in shaping our lines of conduct, whether we struggle to maintain a status quo, to gain some promised land of the future, or to recover a lost paradise. It would be superfluous for us to indicate any of the signs and landmarks showing the mutability of human affairs-history is concerned with recording their course. Even elementary school books show how the agricultural society of Washington's day, with its stage coaches, candles, and sloops, has become the industrial order of our time with its airplanes, electric lights, and ocean 
liners. In the same books is recorded the transformation of colonial societies, with class governments and established churches, into our national democracy without religious establishments, with professed toleration for all.

With the details we are not here concerned. It is the inescapable drive of change under the accumulation of ideas and traditions, under the relentless impacts of science and invention, that sets the fundamental problem in organizing social studies for the schools. In a fixed régime it is possible to establish duties, rights, and responsibilities with a fair degree of definiteness, effective always, everywhere; but in a changing society such crystallization is not only out of the question, attempts to effect it are dangerous to orderly development.

While nearly all will admit that change is a fact of experience, many will draw attention to what they call the permanent elements in the universal flux-the family, the state, property, labor, and religion. Niagara Falls, it may be argued, is not so many million drops of flowing water, but a permanent phenomenon, a form of things 


\section{Requirements of Social Realities}

through which water endlessly streams. But the analogy is misleading. For practical purposes there is no form without substance; when the substance changes, the form bends to the process. It is easy to say to the young that the family is eternal and the statement may echo our deepest aspiration; but the dogma does not help them much in the way of life, when, true to our disciplines of history and anthropology, we must inform them in the next breath about the polygamy of the ancient Jews, the patria potestas of the Romans, the sacrament of the Roman Catholic Church, the civil marriage of modern times, the easy divorce system of Nevada, and the growing divorce rate in the United States.

And what if the particular youngster to whom we happen to be talking comes from a family already broken by separation of the parents, if not by divorce? Again we may insist that the ideal American family is the best conceivable-perhaps all who sign this report will agree on thatbut shall we condemn out of hand as immoral all those who are separated or divorced and the laws which sanction divorce? 


\section{$A$ Charter for the Social Sciences}

It is equally easy to declare that all good citizens should respect the Constitution of the United States; about this there is little dissent; but a child who can read will soon discover that the Constitution provides for changes in its own structure, that many amendments have already been made in it, and that others are always pending in Congress or being advocated by men or women of the highest standing in American life. And a boy or girl who has got into the high school will naturally inquire whether it is Hamilton's or Jefferson's interpretation of the Constitution which is to command our affection and admiration. When the truth is faced boldly, it is a changing world, accompanied by endless diversity of opinion, for which our instruction in social studies must fit the youth of the schools the best it can, fallibly, of course, and yet with an open-eyed regard for the nature of things.

Intimately associated with the changing character of modern society, in an inner but not entirely causal relation, is the second conditioning element in our situation, namely, industrialism. What is called Western or modern civilization by 
way of contrast with the civilization of the Orient or mediæval times is a civilization that rests economically on science and machinery. It is in reality a technological civilization as distinguished from one founded on agriculture and handicraft commerce. The great majority of the boys and girls who pass from our schools no longer intend to engage in farming or planting. Every decade sees a decline in the proportion of people and capital employed in tilling the soil, and even farming itself is being transformed under the impact of machinery and large-scale production.

Under the drive of industrial expansion and invention our civilization becomes still more highly dynamic. Agricultural societies change slowly with fluctuations in markets, the fortunes of governments, the spread of knowledge, and the vicissitudes of wars, keeping their basic habits and institutions intact from century to century. But an industrial civilization founded on technology, science, invention, and expanding markets must of necessity change and change rapidly. The order of steam is scarcely established before electricity invades it; electricity hardly gains a fair start be- 


\section{$A$ Charter for the Social Sciences}

fore the internal combustion engine overtakes it. The demand for new commodities and processes creates new industries, while declines in other directions put old industries out of business. Skilled artisans can never be certain that a new machine will not render their craft useless before they have reached middle life. New callings are constantly opened, demanding unusual talents. Few indeed are the families in which the same occupation now descends unbroken from generation to generation.

All industry becomes dynamic, changeful, requiring for its development extraordinary qualities of alertness, mobility, and ingenuity. Routine skill is seldom enough; capacity for adaptation is the prime source of achievement. And this new life must be led in the midst of urban centers large and small, not in the open country where our ancestors tilled the fields, spun and wove. It must be lived amid circumstances which dissolve the habits and loyalties of agrarian and village times. Therefore, the assumption that the schools can indoctrinate the pupils with fixed ideas and give them definitive skills good always 


\section{Requirements of Social Realities}

and everywhere has little warrant in our industrial civilization.

Besides being changeful in its manifold aspects, this civilization is essentially rational and scientific. Agriculture, in the old days at least, operated largely by rule of thumb. The farmer may still hope to drive away insect pests by exorcising evil spirits; but no owner of an automobile expects to start a balky engine by doing genuflections before the carburetor. Additional illustrations are not necessary. Industrial civilization cannot operate on chance and emotion. It must have at its command facts, the laws of physics and chemistry, all possible information respecting machines, operations, costs, materials, and markets. In a stern imperative it commands all who would serve it or survive in it to get pertinent facts, make calculations, plan to distinct ends, and construct to purpose.

This engineering rationality runs into government and social arrangements. Thirty years ago city planning was almost unknown in the United States, at least as an organized science; now it is represented by a national association, a magazine, 


\section{$A$ Charter for the Social Sciences}

a national conference, university chairs, a practicing profession, volumes of statutes, and achievements of no mean order. From the city, planning extends to the surrounding region. Signs of state planning appear on the horizon in administrative reorganization and in the co-ordination of highway, health, and charitable functions. Although it is not represented in the Federal Government by a single commission or agency, as in many of our cities, national planning is already implicit in the efforts of the Farm Board to introduce regularity into agricultural production, in the Federal Reserve system, in the projects of the War Department for a unified system of waterways, and in the action of President Hoover with respect to united efforts against the worst evils of business depression. "We are passing," said Mr. Hoover, "from a period of extremely individualistic action into a period of associational activities." The world into which our children are to be graduated, for which they are to be prepared, will be a world in which rationality, planning, and intelligent co-operation will have increasing sway in domestic affairs, industry, and government. 
The third conditioning complex to be considered in formulating a program of social studies for the United States is the system of government under which pupils are to live, nearly all of them as active participants. The government of the United States, from bottom to top, is elective, not hereditary or dictatorial. It is avowedly a government of the people, by the people, and for the people. Its form has not been fixed by prescriptive right or tyrannical fiat, but by the process of deliberation and ratification. Its lawmakers and chief executive officials, high and low, are chosen, directly and indirectly, by duly qualified citizens, by plurality or majority vote. They are elected, as a rule, for fixed periods and may be turned out of office by popular vote at the end of their terms. The functions assumed by the government, altering from generation to generation, are determined by the same popular methods, indirectly through elective representatives and in some cases directly by popular initiative and referendum.

While it is true that under our system certain great principles relative to life and property are placed by the federal and state constitutions be- 


\section{$A$ Charter for the Social Sciences}

yond the reach of ordinary electoral majorities and pluralities, none of them is lifted above popular influences and immutably fixed. The Constitution of the United States and the constitutions of the states provide for their amendment by more or less democratic processes. Although it is generally agreed that they should not be changed "for light and transient causes," there is no tribunal beyond the popular forum to which an appeal can be made in each case, save to force, which, as Jefferson said, is "the vital principle and immediate parent of despotism." To this system, a hereditary monarchy or a dictatorship seems to be the only alternative.

And in practice, American government operates under the pressure of political parties. A party is an association of men and women bent on getting possession of the engines of political power and using them to realize the program of principles which they espouse. Whenever the policies and laws of a party in office are not satisfactory to the majority or plurality of voters, as the case may be, then that party may be ousted at the next election and a new one installed. Hence the right to dis- 


\section{Requirements of Social Realities}

sent from the views and measures of the government at any given moment is essential to the operation of the American system, even if it were not guaranteed by constitutional provisions in behalf of freedom of the press and speech. To permit a group of men temporarily in official authority to suppress all critical discussion of its policies and conduct would be to strike at the roots of the whole scheme and transform elected persons into despots. American government depends for its operation as well as its vitality upon discussion, criticism, and the formulation of public opinion. And in this process the boys and girls who go out from our schools do not participate as mere robots, doing what they are told to do. The intelligent among them become creative forces in their communities; they make laws as well as obey them. And the more dynamic become leaders on some scale, for American political institutions cannot function without spontaneous leadership.

Since many of the important policies of government are of necessity highly controversial, instruction in citizenship, if it is not limited to sterile abstractions, cuts into difficult themes and affects 
powerful interests in society. An attempt to conceal this fact would be futile; an evasion would lead to stultification. It would be better to ignore entirely the subject of government in social studies than to confine it to innocuous generalizations on which people agree in theory and disagree violently in practice. Nothing is more disconcerting to children than to find that the doctrines of the schoolroom do not square with the conduct and views of men and women with whom they come into contact in homes, streets, churches, and industries. But because the themes of politics are controversial, it does not follow that they cannot be treated scientifically and impartially. It means rather that only highly trained and skillful teachers can handle them in a way calculated to stimulate intelligence and waken discriminating power among pupils. Given this political system, therefore, attempts to establish a program of social studies in terms of simple dogmas and doctrines are bound to be futile, if not dangerous.

Immense difficulties are here involved; it would be idle to deny their existence; but the schools 


\section{Requirements of Social Realities}

cannot ignore them. All about us in society, whether in times of prosperity or crisis, grave problems are discussed in newspapers, forums, magazines, and by the fireside. Periodically, almost regularly, the governments of great cities are shaken by scandalous revelations and political conflicts. On every hand dissatisfaction is found with our present industrial order-dissatisfaction which ranges from minor proposals relative to unemployment insurance and old age pensions to schemes for fundamental reconstruction. Agriculture in the United States has long been prostrate and in responsible quarters doubts are raised whether it can ever be restored to a high plane of well-being by mere modifications in the historic system inherited from the fathers. Will it be necessary to invent new modes of urban government and to discard large sections of the municipal machinery which once worked with a fair degree of efficiency in conditions relatively simple? It is generally admitted that the aim of our productive structures in industry and agriculture is to meet the requirements of a high standard of living for the masses of the American people. 


\section{$A$ Charter for the Social Sciences}

Will it be necessary for us to make drastic modifications in the customary means, with a view to attaining the ends proclaimed? These questions are being asked in the society in which the schools function by the fathers and mothers of children who are receiving instruction in the social studies. Pupils who have advanced beyond the sixth or seventh grade know that they are being asked and approach their social studies with large queries in mind. It is inconceivable that scholars seeking to establish a workable scheme of instruction in the social studies can ignore them.

Nor is it possible for school boards and administrators to escape the necessity of dealing with these issues. They may, no doubt, consider the questions too perplexing for the classroom or categorically deny their significance. But even a purely negative position produces intellectual results, often reactions more important than those induced by lively discussions. Controversial questions may be excluded from the school books. Teachers may be forbidden to discuss them or to answer questions put by their pupils or to cite books in which problems are considered. In other 


\section{Requirements of Social Realities}

words, a conspiracy of silence may be arranged and enforced in the classroom. Is there any reason for assuming that such a policy will produce results more beneficial than those to be attained by a frank facing of apparent impossibilities? Practical persons may think so, but everywhere students of human history will have doubts. The latter will continue to suspect with Dr. Oliver Wendell Holmes that "to try to think of waterproofing the American mind against the questions that heaven rains down upon it shows a misapprehension of our conditions." The assumption that social difficulties can be avoided by setting up a scheme of social studies on the basis of evasion and omission might well be more perilous to the interests of those who cherish it than either a complete neglect of civic instruction or a frank facing of the realities.

Yet when these contentions are duly admitted as valid, we must be on our guard against adopting the hasty opinion that the public schools can solve the problems of democracy or at least prepare the way for easy solutions. On this assumption it is sometimes urged that the chief purpose 


\section{$A$ Charter for the Social Sciences}

of the social studies is to assure a presentation and discussion of current issues. Out of this, it is said, will come the proper preparation of the people for their historic mission. While this thesis is alluring and is supported by high authority, it should not be taken for granted without examination.

The reason for caution becomes apparent on second or third thought. First of all, there is no assurance that the problems discussed today with such assiduity will be the problems before the country when the children now in the grades have reached the age of maturity. History is in a large measure a record of unexpected crises-at all events of crises not generally foreseen or at best dimly foreshadowed. Forty years ago, the free coinage of silver at the ratio of sixteen to one and the dissolution of trusts were the pressing issues; now they are, at most, of secondary importance. Burning questions of the hour may be ashes tomorrow.

While there might be a general agreement on certain questions of weight for present consideration in the schools, any selection made by educa- 
tional authorities might well leave out of account issues of pressing concern-issues now discussed by obscure individuals beyond the reach of headlines. Hence, besides being temporary in its nature, a list of problems will be partial, one-sided, and perhaps trivial in spots. It would be a bold person who would attempt to make an artistically balanced presentation of the problems of democracy to be discussed in the classrooms of our primary and secondary schools with a view to practical solution.

If the dilemma is more closely scrutinized, doubts may be raised about the possibility of solving such problems by classroom consideration. It is not to be imagined that champions of this hope would rely upon scholars and teachers to dispose of all debated issues by positive conclusions. On the contrary, perhaps the most ardent adherents of this school will probably insist that the teachers must leave the problems open after presenting the substance of conflicting views. How then can the schools contribute to the solution of great questions? They cannot assume infallibility, provide remedies for all social discomforts, and send the 


\section{A Charter for the Social Sciences}

children out with dogmatic medicine already prepared.

For many of the problems even the wisest statesmen have no certain solution; it may happen that some of them will disappear entirely or never be solved by any process. The schools have no access to super-wisdom. If they do, then, educators might well take over the government of the country. Even the professors in graduate schools would scarcely want to assume that responsibility. When we take into account the inadequate preparation of thousands of teachers in the public schools, their inexperience, and the heavy turnover among them, we must confess some misgivings about expecting a facile solution of the problems of democracy through and by the public schools.

This modest conclusion is reinforced by the indubitable fact that in large sections of the country, perhaps in most of the country, it is impossible for teachers to discuss some of the pressing issues of the hour without raising a storm of controversy in their communities and jeopardizing their positions. What, for example, would be the 


\section{Requirements of Social Realities}

result of a fair and temperate consideration of the relations of the United States to Soviet Russia even in the best-administered schools of the country? Ordinarily the most judicious attitude on the part of the teacher is immediately condemned as sheer Bolshevism. Hundreds of individuals and societies are crouching continually to spring upon the teacher who merely raises the question. In some communities supposed to be enlightened teachers are forbidden to discuss Russia without denouncing her form of government and system of economy. According to the testimony of members of this Commission, teachers of history in a certain state of the Union do not dare to allow their neighbors to know that they are studying in a scientific spirit the history of recent times in Russia or have books on the subject in their possession.

Another item is to be considered by those who seem to imagine that the public schools can send children out armed in the full panoply of knowledge to solve the problems of democracy: that is the fact that the schools are merely one agency for the development and distribution of knowledge, 
and their importance can readily be overestimated. It is a lesson in humility for students of history to recall the contributions of organized learning to struggles of nations to find self-government in the past. Their chief rôle, and it may well be argued, their proper rôle, has been conservation and indoctrination rather than exploration, adventure, and transformation. It is worth while to recall that the American people solved one of their greatest questions before the public school system was founded, namely, the establishment of the national Constitution. Experience, daring, and maturity are necessary to large enterprises in democracy, and the schools have no monopoly of virtue in this field.

From what has been said, therefore, it follows that while some of the problems of democracy must find a place in the social studies program, they cannot form the entire substance of it or work wonders even when they are duly introduced and exploited. Furthermore, a wide knowledge of facts and a discipline in thinking are the prerequisites to a fruitful consideration of controversial questions. Here, it seems, the schools 


\section{Requirements of Social Realities}

may lay their emphasis, with less danger to their instruction and perhaps more profit to the country. To be sure, many facts presented should be immediately germane to problems, and the mind may be whetted on live issues as well as dead issues, but there is something to be said for giving pupils a thorough grounding in the historical records of human experience before they attack the more elusive questions of the living present.

While all this is admitted by way of limitation and condition, civic instruction in the schools in the United States must of necessity lay stress on the democratic process of government. It must deal with masses and have a democratic slant to its organization of materials and emphasis. While a dictator or despot may issue orders and shoot those who refuse to obey, government in this country must defer and bend to the multitudinous wishes of the varied population. Social science, of course, will seek to explain the rise and methods of dictatorships and the rôle of dictators in times of crisis, but it cannot say that the subject matter of its inquiries, namely, society at large, is or 
ought to be without will or force or purpose, unless it abandons its own principles and findings. The aim of civic instruction under this head, then, is to strengthen democratic institutions, make clear their working, point out defects generally agreed upon, provide more effective leadership, illuminate every possible corner of the political scene, and promote habits of critical fairness among the electorate. This cannot be done by reciting creeds and repeating ceremonial formulas, but by making realistic studies of the actual pressures operating in politics and government and the concrete issues behind the verbalism of partisan oratory.

It is not only in and through certain domestic institutions, political, economic, and social, that the citizen lives and discharges his obligations. American society operates on a world stage. Civic instruction must reckon with that reality. Even internal history is not made solely by internal forces. France is a republic today largely because Germany destroyed her monarchial institution on the field of battle; and Germany is a republic mainly because her imperial system was broken in 
Requirements of Social Realities

the World War. By rapidly multiplying ties of trade, capital investment, and intercourse, the United States is being woven ever more closely into a world fabric, drawn into a network of international arrangements. It is officially represented in numerous international agencies. It continually enters into conferences with other powers for the purpose of composing differences and reaching agreements enlarging, limiting, or defining American rights. It cannot consider any phase of national defense without calculating the possibilities of rivalry ending in grave consequences. Indeed, many of its leading statesmen see safety in the limitation, rather than the expansion of armaments. Such at least is the underlying assumption of the Washington pacts of 1922 and the London Treaty of 1930. And the renunciation of war as an instrument of national policy by the Kellogg Pact, coupled with a pledge to seek the peaceful solution of controversies, confirms a tendency already well marked-a tendency restraining the once unlimited privileges of force. The rights and obligations of the United States in the family of nations, therefore, come clearly 


\section{$A$ Charter for the Social Sciences}

within the circle of thought which must be covered by social studies.

There is danger of taking this obligation too lightly, of treating it as a form of geniality to be encouraged by platitudes, of regarding it as highly unreal. It has been said that the child is usually taught nothing about sex, and it may be added that ordinarily he is taught to believe realisticaily in the existence of only one nation. To be sure, through geography and history he learns something about other countries, but they are generally viewed as abstractions remote from his life as an American citizen. Once, of course, when the United States was agricultural and more largely self-sustained, this was quite natural and perhaps defensible, but in this age of foreign trade, migration, international credits, radios, and cables, political boundaries are not so absolute and international relations become as significant and fateful as domestic affairs. Social education cannot help a given society attain its just ends unless it lays bare the structure of international relations and emphasizes the importance of the kind of national behavior essential to the rational conduct of inter- 


\section{Requirements of Social Realities}

national affairs. In other words, the domestic scene must be firmly fitted into the world scene.

This aim is not to be accomplished by treating international relations casually at the end of some particular course of instruction but as fundamental to the development of nearly every aspect of domestic life. The economic and cultural ties which bind the peoples of the earth into a single web are no less real than are the forces of internal evolution. If decency, fair play, forbearance, and respect for responsibilities are necessary to domestic felicity, they are equally necessary to the maintenance and promotion of international harmony. A well-governed nation, in its intercourse with other countries, avoids chauvinistic bigotry, does not covet its neighbor's goods, stands firmly for substantial rights without threats or boasts, and assumes that its associates in the family of nations have as much honor as it has. In American ideology war is not a virtue to be sought but an evil to be avoided. Long cherished widely among individuals, the ideal of peace has now been incorporated in the Kellogg Pact, which renounces war as an instrument of national policy and binds the 


\section{$A$ Charter for the Social Sciences}

contracting parties to seek the solution of all disputes and conflicts by pacific means. To create in the popular mind the conditions favorable to the continuous realization of this policy is an obligation imposed by the nature of things and the law of the land on teachers of social science.

\section{THE CLIMATE OF AMERICAN IDEAS}

In this changing society, industrial and scientific in character, governed by the popular process, and international in affiliations, all is not determined in advance; if it were, the sole function of instruction in social studies would be to prepare citizens for their fate. No doubt civilizations to some extent "grow" automatically; but in part at least they are made by conscious and determined effort under the impulse of ideas and ideals inherited from the past and evolved out of experience. The Constitution of the United States was formed and its ratification secured by the immense effort of a relatively few citizens. City plans are made by engineers and architects and put into effect slowly by the insistent resolve of 


\section{The Climate of American Ideas}

leaders inspired by visions of work that can be done. What is potential, as well as what is, must enter into civic instruction if it is to be more than a sterile transmission of acquired customs and habits.

It is not possible to escape this imperative by any intellectual legerdemain. If the schools do not participate in creative enterprise, it will go forward without them, reducing their significance in the educative process. And since this report is shaped with reference to the total situation before us, rather than any narrow view of formal education as such, it must bring to a focus the fundamental national ideals bequeathed to us by time, and emerging from the fluid reality of contemporary experience. The attempt is hazardous, no doubt, and this Commission will make no claim to infallibility, but taking the view that education is for life as lived and as it may be lived, we are bound to consider the enveloping ideas of our age no less than its evident institutions and tendencies.

If we examine narrowly the competing ideas of society which are offered by our time to those 


\section{$A$ Charter for the Social Sciences}

who concern themselves with civic instruction, we find that three emerge as the most persistent. The first is ideological: the present order is the best of all possible worlds and the business of learning is to rationalize the apparently predominating scheme of things. On close analysis, this framework of philosophy dissolves into defense mechanisms historically inherited or practically developed by groups and interests in society primarily engaged in preserving particular forms and processes. The second is utopian-a conception of an ideal state, a scheme of perfection which if realized would become static; stemming from certain ideas emphasized by the first French Revolution, it accepts the possibility of perfectionism here and now. The third tenacious social idea may be called progressive; it accepts neither the perfectionism of current ideology nor the perfectionism of utopia, but is founded on the assumption that what we actually have to deal with in reality is a process, a changing order of things which carries along with it an ideological heritage, and bears within itself the possibilities of a more perfect order of things, never utopian and 


\section{The Climate of American Ideas}

fixed, but always involving the perils of choice and the advantages of improvement. The ideologue praises a perfection which he believes to exist here and now. The utopian praises a perfection which is to exist. The progressive combines elements of both. His mental picture of the social order is only a partial mosaic, not a fixed and copper-riveted status quo, or utopia; and in that partial mosaic are elements of the existing arrangements of things, elements of things already in the process of formation, and elements of things deemed desirable and hoped for.

If it be urged that the teacher of social studies should have nothing to do with ideas so controversial in nature but must stick to "facts," an invincible answer is forthcoming. Since all the facts cannot be assembled and presented in any scheme of instruction, a selection must be made, and in the arrangement, since some numerical order is necessary, emphasis cannot be avoided. Every statesman, every judge, every informed citizen who acts on something more than prejudice has in mind a more or less logical picture of an ideal social order to be preserved or realized; and in 


\section{$A$ Charter for the Social Sciences}

concrete cases of controversy throws his weight on the one side or the other in accordance with his mental picture. The teacher of social science can only escape presenting the necessity of choice in social affairs by fleeing from the world of reality to a land of abstraction. If this is the alternative, then civic instruction might as well be taken out of the schools. By its intrinsic nature, social science requires some picture of the process in which we live and work and when it is realistically conceived it must deal with what is here and now and also with what is emerging from the here and now.

From this point of view, it appears that any social science worthy of the name must objectify itself in the development and improvement of individuals, institutions, human relations, and material arrangements already in course of unfolding in the United States. The people of this country are engaged in no mere political experiment, as often imagined, but are attempting to build a civilization in a new natural setting, along original lines, with science and machinery as their great instrumentalities of work. Though an off- 


\section{The Climate of American Ideas}

spring of European civilization, America has never imported a large part of the Old World heritage and is constructing a social order of many ingredients that are distinctly unique in emphasis at least. We cannot import civilization wholesale from Europe. To be sure, pictures may be bought, musicians brought over at handsome figures, castles may be carried across the sea and transformed into mansions for plutocrats, and ideas transferred, but civilization is no borrowed plumage, no plaster decoration that can be stuck on any kind of a solid structure. Having rounded out the Continent, Americans have turned in upon themselves and are taking time to wonder about the next great tasks ahead. While a few critics go abroad for inspiration, while the wise search for ideas wherever they may be found, the great body of thinkers still agree with Emerson that we must stand fast where we are and work out our destiny along lines already marked outbuild a civilization with characteristics sincerely our own, in harmony with historic ideals and yet incorporating novel practices adapted to changing needs. As in all other civilizations four aspects 


\section{$A$ Charter for the Social Sciences}

will always be in the foreground-political, economic, ethical, and esthetic.

Nowhere is the predominating ideal of a progressive society set forth more cogently or with greater authority than in the Constitution of the United States as written and as interpreted by legislative enactment, judicial exposition, and political practice. Its fundamental purpose, as set forth in the preamble, is "to form a more perfect Union, establish justice, ensure domestic tranquillity, provide for the common defense, promote the general welfare, and secure the blessings of liberty to ourselves and our posterity." The heart of the matter is the promotion of the general welfare, liberty, and justice; for all other objects in the enumeration are evidently means to this end. It is the general welfare that is emphasized. The term seems vague, but it rules out the exclusive welfare of special classes and privileged orders; American society does not exist for their benefit, but for the general good. And when the phrase is explored as to content, real and potential, with reference to authoritative opinion and practice, it affords guidance in the concrete. 
Starting with the individual, that welfare means a sound body safeguarded by all the knowledge, means, and services commanded by modern science. An immense body of laws, a vast array of institutions, and wide-spread practices, federal and local in origin, bear witness to this assertion. The right to be well-born physically and mentally, the obligation to transmit this right unimpaired to coming generations, are fundamental to the realization of the ideal expressed in the opening lines of the Constitution. Correctly conceived, this is no mere matter of personal hygiene, important as that is. It involves many aspects of social livingsafety in mines and industries, the protection of water, milk, and food supplies, housing, and the planning of cities, rural sanitation, hospital services, care for the sick, injured, and convalescent, quarantines against contagion, and many other phases of correct living and working.

One thing seems to be established beyond doubt by social statistics, namely, that the span of life has been lengthened by modern science and economy. "Public health is purchasable," declared a former health commissioner of New York City; 


\section{$A$ Charter for the Social Sciences}

"within natural limitations a community can determine its own death rate," and to this should be added, "its own state of physical well-being." Such contentions may be defended not only on grounds of economy, because sickness causes great losses in wealth, but also on the grounds of the right to life, liberty, and the pursuit of happiness. By a competent authority we are told that "in the schools of the United States today there are one million children who are looking forward to becoming business men or housewives or clerks or industrial workers, but who will end their days as inmates of institutions for mental diseases, if present ratios hold."

And much depends upon the schools, for Dr. C. E.-A. Winslow goes so far as to say that mandatory health laws could safely be removed from the statute books if health officers were "given in exchange adequate funds for a full health program of education and of services along clinic and nursing lines."

Here, then, is a basic fact for the formulation of a scheme of instruction in social studies. Here is an ideal increasingly prominent in the thinking 


\section{The Climate of American Ideas}

of those concerned with a better future in America. It does not imply that all sick and defective people are useless; some of them may be happier and more industrious than others enjoying perfect health; but that physical well-being is one of the great objects to which American knowledge and enthusiasm are and should be devoted.

Next to physical health and intimately associated with it is economic welfare. According to the national ideal, the rich natural endowment of the United States is not dedicated to providing luxury for privileged classes, but to assuring a reasonable standard of living for the whole people. Engineers tell us that science has solved the problem of production and, unless overcome by rising population, can assure a decent minimum for all who are willing to labor. In overcrowded China, dependent upon agriculture, undeserved poverty may be entirely unavoidable, but under a régime of science and machinery it can be eliminated. No doubt the problem of distribution involved in this operation is complex and difficult; nor is any golden way to perfection immediately visible. The provision of ample capital 


\section{A Charter for the Social Sciences}

accumulations and the protection of initiative are not to be lightly accomplished, but the highest of modern statesmanship, political and industrial, is now pledged to raising and safeguarding standards of life, preventing undeserved poverty, and establishing barriers against unemployment. This is one of the insistent tasks of American citizenship and it conditions that type of civic instruction which deals with all the dynamic enterprises of American civilization.

Correlative with the determination to raise all who labor above the mere subsistence level is the conviction that it is the duty of all to perform useful labor and to respect its utility to society. An able-bodied person who does not work is a social parasite, and in a healthy social order is so recognized and treated. In America there is no place for a class which lives by exploitation and specializes merely in leisure as a form of pleasing life. Undoubtedly there are at present many highly respected callings which serve little or no productive purpose and would be regarded as prehensile in a more discriminating society. On the other hand, there are many branches of labor, indispen- 


\section{The Climate of American Ideas}

sable to the life of the nation, which condemn those who enter them to an inferior social position. But if prevailing custom lends sanction to this state of affairs, it must be admitted that the ideals of the men and women who have led in the development of the United States give no countenance to it. The spirit of the modern age runs against it. Those who exploit society and return no compensating services are enemies of society. No social science worthy of the name could teach any other doctrine in the public schools sustained by society.

But labor, although a duty, is not an end in itself, nor does it occupy the whole of life. In the American scheme, leisure is a right and the provision of leisure for the enjoyment of life is one of the objects of enlightened industry. No drudge can truly share the fruits of civilization, and a fairer distribution of the blessings and benefits of civilization is one of the major interests of American statecraft. Already in many branches of industry a part of the ideal has been attained in shorter hours, and nowhere is the long day of exhausting toil, though still prevailing in many 


\section{$A$ Charter for the Social Sciences}

places, defended any more as one of the necessary evils of economy. If some have too much leisure and others too little, that is a wrong which social ethics is under obligation to correct.

Whatever remains to be achieved, leisure is even now so abundant that its ideal use is one of the problems of education. Exploited by cheap and often degrading commercial amusements, it may be turned from an opportunity into a blight; it may be devoted to activities that re-create and refresh the spirit, or diversions that contract and lower vitality. American opinion is deeply concerned, therefore, with the preparation of the coming generation for a better organization of life outside of industry, and for the pursuit of higher forms of human interest in leisure hours. In fitting themselves for a life of health, labor, and leisure, all are entitled to the fullest possible educational opportunity. This is another American ideal so firmly established that it is beyond question. It is also agreed that this opportunity should be limited in time and nature only by the ability of the individual to profit from its benefits. Although these generalities will scarcely be ques- 


\section{The Climate of American Ideas}

tioned, we are still far from the goal. In spite of our free schools and extraordinary educational advances, authoritative opinion holds that education depends too largely on family tradition and circumstances. To prepare the ground for a more even adjustment of the balance is one of the objectives in the teaching of social science. Yet at the same time emphasis on the right of the individual to educational opportunities carries with it an equal emphasis on the obligation to shape the higher learning with reference to social interests. There is no reason why society should tax itself to provide educational facilities for those whose chief concern is the exploitation of the public to personal advantage.

Universal educational facilities will lead pupils into blind alleys, however, unless they can find in after life a certain equality of opportunity to apply the talents which they have developed in school. This, too, is a cardinal principle in America. "Our aim," said President Roosevelt, "is to recognize what Lincoln pointed out: the fact that there are some respects in which men are obviously not equal, but also to insist that there should be 


\section{$A$ Charter for the Social Sciences}

equality of self-respect and mutual respect, an equality of rights before the law, and at least an approximate equality in the conditions under which each man obtains the chance to show the stuff that is in him when compared to his fellows." With the opening of callings to women and their acquisition of political rights, they have also come within the circle of equal opportunity. To break down special privileges and level up the channels to achievement is another idea of American life with which civic instruction must be squared.

This creed is not a mere hypothesis, pleasing to a few sponsors. It is one of the fundamental facts of the American system abundantly illustrated in processes for securing a more equitable distribution of wealth through taxation, the regulation of private enterprises, and other social devices such as insurance, public and private. Income and inheritance taxes, for example, afford statutory evidence. Our greatest statesmen have accepted this form of taxation and have approved the employment of the proceeds for raising the common level -education, highways, public health, old age 


\section{The Climate of American Ideas}

pensions, subsidies, and other types of enterprise coming under the head of general welfare. Social science must treat this practice as one of the emergent realities of American life.

Akin to the attack on the inequalities of benefits and opportunities is the effort to eliminate undeserved poverty through old age pensions, mothers pensions, and projects for dealing with unemployment. Whereas the distress due to industrial crises was once regarded as a fatality to be endured, it is now viewed by all competent American statesmen as a problem of civilization to be solved by the application of rational methods. In other words, one of the major aims of American civilization now in process of realization is the planning and management of economy in such a fashion as to eliminate the poverty and squalor which have cursed the masses in all previous civilizations. On the practical side this may be called the supreme effort of the modern age and though often criticized as "materialistic" in nature may properly be viewed as the great economic objective of our time.

The accomplishment of this purpose without 


\section{$A$ Charter for the Social Sciences}

unduly burdening industry or diverting too much capital from productive enterprises is implicit in city, state, and national planning with particular reference to streets, housing, highways, waterways, natural resources, and public utilities. Many great projects have already been executed. Others are under way. Once confined largely to urban areas, planning has now been extended to include the whole country and takes concrete form in nets of highways, rural free delivery, agricultural extension, waterways, and forestry, for example. While the need for private initiative and enterprise has not diminished, the necessity for cooperative planning and community enterprise increases with the pressure to raise the whole level of American civilization. The description of this process, the elucidation of its major problems, and the promotion of grand designs are therefore among the responsibilities imposed upon social science by the necessities and ideals of the American scene-all with the great purpose of securing to the individual an equality of opportunity to share in the riches of civilization.

In keeping with this emphasis on equality of 
opportunity is our insistence on individual liberty in other relations. Nothing is more evident in the American tradition than the right of the individual to resist excessive social pressures. $\mathrm{He}$ is entitled to his rest and to freedom from the continuous demands of society, to a high degree of privacy in personal affairs, to individuality in dress, mode of living, and religious, economic, and political beliefs. In a word, he should be provided with the means of escape from the severe mechanization which tends to characterize life everywhere in the present era. This does not mean evasion of social responsibilities, but the widest possible liberty outside of the necessities of an orderly social life. No doubt in practice the line of division is difficult to discover, but, in view of all the efforts to "socialize" children, it is appropriate to call attention to the dangers of goose-step regimentation and lay stress on some ancient privileges which must be safeguarded if intellectual death is not to overtake us.

At bottom, this is another way of saying that toleration is a fundamental American principle which ought to control the formulation of objec- 


\section{$A$ Charter for the Social Sciences}

tives in civic instruction. Perhaps toleration is not the just word, implying as it does a certain condescension on the part of those who practice it. It might be better to say a firm belief in the beneficent effects of freedom of thought, in the right of others to their ways of life and opinion as a good in itself and the safest guarantee of progressive development. American society is a compound of many races, creeds, cultures, and convictions as to values. This should be a matter for congratulation, not for dismay. And if the American experiment is to work out successfully and smoothly, friction must be reduced, antagonisms minimized, clashing points of contact harmonized. Attempts to impose a common stereotype of dead-level behavior on the whole mass will end in failure-embittering controversies in the meantime. To explain this complex to students, to lay the groundwork for mutual understanding, and to inculcate respect for the opinions of others is certainly one of the fundamental functions to be discharged by teachers of social science.

Underlying all these national ideals is a belief that the lot of mankind can be continuously im- 


\section{The Climate of American Ideas}

proved by research, invention, and taking thought. This is the philosophy of progress and if rightly conceived is one of the noblest conceptions yet created by the human mind. The environment and conduct of men and women can be modified by effort in the light of higher values and better ends. Human relations, constitutions, economic arrangements, and political practices are not immutably fixed. If there is anything which history demonstrates, it is this generalization. All legislation, all community action, all individual effort are founded on the assumption that evils can be corrected, problems solved, the ills of life minimized, and its blessings multiplied by rational methods, intelligently applied. Essentially by this faith is American civilization justified.

It has no decorative classes established by law, giving grace and elegance at the top to offset poverty and ignorance at the bottom. The cultivated classes of Europe, according to Amiel, represent "aspirations toward a harmony of things which everyday reality denies to us and of which art alone gives us a glimpse." The American masses, by contrast, are striving toward a certain harmony 


\section{A Charter for the Social Sciences}

in reality that can be vouchsafed to the humblest willing to pay the price of a quest for it. Therein lies the substance of the American ideal so often scorned by European writers given to comparing the superiority of privileged orders with the commonness of democracy. Those who do not like this American ideal may flee from it; all others must work under the limitations of its influence.

Although, in this development of ideas, emphasis has been laid on material means, the pressure behind it has come mainly from ethical impulses-the desire to see a more even distribution of the benefits of civilization. Assailed as sentimental and humanitarian by some practical men of affairs and by one school of professed humanists, it nevertheless stands on its own merits and is to be defended on good humanist grounds. Civilized people have reached such a stage in moral evolution that they cannot sit comfortably in the midst of plenty while starvation and misery do devastating work a stone's throw away. Whether this is the fruit of religion, philosophy, or revolt, or all three, it is an emergent reality in every modern society that makes pretensions to 


\section{The Climate of American Ideas}

civilization. Social science cannot ignore ethical considerations; otherwise it would become a branch of inert scholasticism without direction or motive force. At each given moment, it is under obligations to select the striking ethical propensities apparent in society, consider their practical upshot, and indicate the various forms which they may take in the advancement of the good life. Ethics gives to civics a dynamic quality.

If ethical considerations recommend a wide distribution of the benefits of civilization, they likewise enjoin a simplicity and sincerity of living which inevitably run contrary to the habits of luxury and extravagance so widely praised in the United States as indispensable to the good life. The average citizen, particularly if he lives outside the limits of a small rural community, finds himself caught by an endless competition in irresponsible and ostentatious display, largely on account of the tendency to accept the pecuniary standard as the measure of success and achievement. What is lacking in natural propensity is supplied by the high-pressure salesmanship which stimulates unnecessary wants, subjects people to a 


\section{$A$ Charter for the Social Sciences}

barrage of appeals to vanity and inferiority fears, awakens crazes, phobias, sensations, and inflated ambitions, and exploits health, beauty, and taste in the interest of money-making. To sales pressure is added the pressure to join clubs, associations, and orders which add to the confusion and complexity of life and diminish its deeper satisfactions.

To counteract these tendencies and emphasize the saner standards of life is one of the functions of civic instruction. While the drift just described is marked, there are imperatives against it which the wise cannot escape. At bottom America gives a greater homage to Emerson, whose princely income amounted to about $\$ 2000$ a year, than to Jim Fiske with his millions, his loud clothes, his fast horses, his jewelry, and flashy equipages. It is the business of social ethics to criticize and expose the perils inherent in animal materialism and to bring into active influence standards of moderate and sincere living. This can be done by laying before children possible alternatives in modes of life and the importance of sane choices in the use of money and leisure. Classroom discussion of 
The Climate of American Ideas

subject matter pertinent to this issue can accomplish something; the encouragement of individuality, still more; and the example of the teacher in public and private relations reaches deeper than the formalities of the school.

Again, if in the course of American development, emphasis has been laid on the material aspects of culture, this does not mean that all American life is to be subdued to the exigencies of utility without reference to esthetics. It simply means that art and beauty, if they are to be genuine, must work their way through the medium which society in the United States provides. Even in their higher forms they have seldom been wholly separated from practical uses, for such separation carries sterility with it; and in America they must inevitably be nourished in relation to the major interests of this civilization. Industrial art, architecture, and community planning are channels through which esthetic impulses may be and are being realized in the United States. On this ground, no less than for intrinsic reasons, social science is as much concerned with esthetics as with other phases of life. 


\section{$A$ Charter for the Social Sciences}

Instruction in history can cover the story of art as well as the evolution of political and economic institutions; if at present it is neglected the disease is not incurable. Civics can give as much space to town planning and regional planning as to taxation-and with no less material and spiritual advantage. Economics can concern itself with the appearance as well as the functioning of factories and workshops. When better understood, social science will teach that industry and business are founded on civilization and would perish in a land entirely dominated by profit-making utility. This is one of the ironies, if not laws, of history.

Nor is this so alien to American experience as some critics would have us believe. From the beginning of our history, the poorest among us have desired to mingle with their work and recreation some elements of symmetry and beauty. In spite of the heavy handicaps imposed upon a pioneering people engaged in subduing a continent, the esthetic interest has been both latent and potential in American life. It was vigorously expressed in colonial architecture and handicrafts. If with the first industrial revolution it was almost buried out

$$
76
$$


of sight in ugly factories, squalid towns, dirty streets, run-down houses, unkempt farms, and cheap, machine-made goods, it was never lost to view. In our own time it comes to fruition in the best business and industrial architecture, domestic architecture, interior decoration, town planning, landscape gardening, painting and drawing, and in commodities of common use. Bread alone makes life possible, but not tolerable. Social science in the schools, therefore, must bring forward the esthetic interest, illustrate it by notable examples in letters and the arts, indicate its uses and potentialities, inculcate respect for it, and show how through individual and community action it can be more richly and effectively embodied in the visible and outward signs of American life and in the tastes and graces of the home.

From esthetics, cherished even by the poorest in some form, it is but a step, an inevitable step, to the promotion of interest in literature as a reflection of and a stimulus to the good life. To American concern about letters, thousands of libaries bear witness, even though a knowledge of literature, like esthetic appreciation, is too often treated 
not as a substance of life but as a decorative addition to bread and butter. If to some it seems remote from the theme of civic instruction, their warped view should be corrected by reference to certain underlying realities. The subject matter of social science is the subject matter of letters. Great poets, essayists, novelists, and critics often penetrate more deeply into the social order than professed writers on that theme, for, as John Morley says, they represent mankind in its most enormous intellectual movements. Many of the classics in economics, history, and politics are also classics in letters. A nation without them is shabby in spirit. Letters reflecting deep currents of humanity inform, inspire, and illuminate living in all its aspects; letters which do not are ephemeral, if not anti-social, in character. Since this is true, social science in the schools has a duty to encourage literary ambitions and interests among students. In this way it can counteract the cheap, flashy, and degrading trash which floods the market, set up standards of judgment, and raise the tone of those who write as well as the taste of those who

$$
78
$$




\section{The Climate of American Ideas}

read-no mean contribution to our supreme object-the making of a civilization.

At peril of making wrong guesses in some directions and raising undesirable controversies in others, we may venture to make a distillation of American history-to summarize in tabular form some of the goals which the American nation seems to have set for itself-goals which must of necessity shape instruction in the social studies:

r. National planning in industry, business, agriculture and government to sustain mass production of goods on a high level of continuity and to assure the most economical and efficient use of our material resources.

2. The expansion of insurance systems to cover protection against sickness, old age, unemployment, disasters, and hazards to civilized life.

3. Universal education from the earliest years of youth to the last years of old age, including public schools, colleges, institutes for adult education, and libraries.

4. The perfection of systems of transportation -rail, waterway, air, and highway-linking all 
parts of the country and facilitating commerce, travel, and intercourse.

5. The development of city, community, regional, and state planning, co-ordinated with national designs, with a view to giving to all the people conditions for living and working that are worthy of the highest type of civilization.

6. The development of national, state, and local parks and kindred facilities for wholesome recreations within reach of all, offsetting and limiting the pressures and distractions of commercialized amusements.

7. Expansion of present facilities to include a national program of preventive medicine and public safety to reduce the death rate, diseases, and accidents to the lowest possible minimum, supplemented by universal hospitalization to care for unavoidable cases of sickness and accidents.

8. The conscious and deliberate encouragement, both public and private, of science, letters, and the arts, not as mere ornaments, but as organic parts of the good life.

9. The preservation and expansion of a reasoned equality of opportunity for all men and 


\section{Framework of Programs}

women to unfold their talents, win rewards, seek appreciation in public and private life, employ their creative impulses, and reach distinction in the various fields of human endeavor within the map of civilization.

ro. Co-operation with the other nations of the earth in promoting travel, intercourse, commerce, and exchange on the faith of the declaration that war is renounced as an instrument of national policy and that the solution of conflicts is always to be sought on the basis of peace.

In making this summary, we do not include any novel or untried ideas but merely enumerate principles already widely realized in practice or in process of application-principles essential to an integral concept of the national ideal.

THE FRAMEWORK OF LAW AND ESTABLISHED PROGRAMS

It is not merely the nature of the social studies and the realities of established institutions and ideals that set the conditions for determining a scheme of civic instruction. School authorities are also subjected, as a general rule, to statutory limi- 


\section{$A$ Charter for the Social Sciences}

tations in respect of their program of studies. A survey of such legislation made in 1925 showed that the following topics had been made obligatory for the elementary school curriculum in ten or more states:

I. Nationalism-flag exercises and display, observance of special days, state history and constitution, civil government, Constitution of the United States, citizenship, and patriotism.

II. Health and prohibition-effects of stimulants and narcotics, physiology and hygiene, physical education and personal hygiene.

III. Safety-fire drill and fire prevention.

IV. Humane habits-humane conduct and protection of life and importance of animal and bird life.

V. Religion and ethics-values of benevolence, integrity, truthfulness, and similar virtues, and Bible reading. ${ }^{1}$ Other states set additional themes and a few have "pure history laws" which require the presentation of certain topics in a prescribed manner. Whatever teachers may think of

1 J. K. Flanders, Legislative Control of the Elementary School Curriculum, 1925; Report of the Committee on Propaganda in the Schools, N. E. A., July, 1929, page 15.

82 
the utility and appropriateness of any particular topic, they are supposed to teach it, if they are ordered to do so by law.

Provisions of law respecting objectives in social science are supplemented by the demands made on the schools by powerful associations of private citizens-economic, religious, patriotic, racial, sectional, military, cultural, and moral. As long ago as I894, Henry Adams directed the attention of the members of the American Historical Association to the fact that they stand in the presence of four great organized forces in modern society: the church, the state, property, and labor. Perhaps it would be safe to say that all other "drives" on the school curriculum have their origins in or near these centers of power. Since, however, the nature and purpose of the various "pressure groups" are fully considered in another report to be issued by this Commission, it is unnecessary to do more than refer to them in connection with this background summary. Whatever teachers may decide to teach, in all possible fairness and impartiality, will be subjected in application to strong impacts from particular interests. 
Although there is some vagueness in the avowed aims of many pressure organizations, only a few of them are radical in purpose or propose any violent departures from the accepted scheme of things. The designs of the major portion may be characterized as conservative-opposition to radicalism, socialism, Bolshevism, pacifism, internationalism, and other ideas which are alleged to be incompatible with "one hundred per cent Americanism." On this positive side their programs include "training in patriotism," "development of faith in American institutions," "training in flag etiquette," "special observance of patriotic holidays," "tributes to national heroes," "the advocacy of preparedness," "the memorizing of national hymns," "pledges of allegiance," and similar "formulas" of Americanism. And for each of these devices are usually furnished a content and animus conforming to the interests of the particular group or association supporting it.

While paying proper respect to statutes and recognizing the place of symbols in the instruction of youth, we cannot be unmindful, however, of perils in over-simplification. By way of illus- 


\section{Framework of Programs}

tration we may take a concrete example. Instruction in the Constitution of the United States is now widely required by law. If to the average mind the Constitution seems simple, it is not so in reality. "The provisions of the Constitution," we are warned by Mr. Justice Oliver Wendell Holmes, "are not mathematical formulas having their essence in their forms; they are organic living institutions transplanted from English soil. Their significance is vital, not formal; it is to be gathered not simply by taking the words and a dictionary but by considering their origin and the line of their growth." Some passages of the document, of course, can be readily understood by the young; for instance: "The Senate of the United States shall be composed of two Senators from each state." But many of the most important provisions are not within the grasp of any child of the public schools, are highly cryptic, and subject to debate and interpretation. Obviously no scholar who has given years to the study of the Constitution, no teacher who has advanced beyond an elementary consideration of the subject, can or will dare to stereotype all its articles and clauses 


\section{$A$ Charter for the Social Sciences}

into neat formulas for automatic insertion into juvenile minds. They cannot escape knowing that the Constitution has been and is being interpreted in various ways, that in practice it is extremely flexible, and that if it is to endure it must encompass adaptations to the developing facts of American life.

While teachers are prepared to render to it all the homage due to the fundamental law of the land, they are aware that it provides for amendment, that amendments have been made, and that additional amendments are constantly presented to Congress for consideration. If public school instruction in the Constitution takes the form of artificial tabus never contemplated by the men who framed it, if its essential spirit of progressive adaptation to the needs of society is neglected, if it is transformed from its original nature into an iron framework to be fixed upon the mentality of the people, then the very ends of its establishment will be defeated and the political conflicts of the future cannot be resolved within the rationality of the law. No fact of natural science is more positively established than this, and scholars 
will fail in their duty if they do not enter a caveat against instruction in the Constitution which substitutes incantation for research in its history and genuflections for thought about its underlying purposes.

Besides finding itself in the midst of numerous conditioning circumstances, such as those outlined above, this Commission, at the beginning of its constructive operations, discovers that a large part of the field is already occupied by programs, traditions, and slogans representing in many cases matured and generous thinking. For years, the subject of civic instruction has received the attention of teachers, supervisors, specialists, educational philosophers, and professional associations. Here, as in other departments of life, are evidences of law and chance, haphazard growth and deliberate effort.

Those who teach and write in the domain of social science in universities and colleges, even when they disclaim all didactic motives, consciously or unconsciously, aid in determining the forms and subject matter of instruction in the schools, by their choice of materials, their elimina- 
tion and their emphasis. At all events, what they teach and write has an effect on students who come within the range of their influence; by accident or design, it helps to set the pattern of civic training in the lower ranges. Although their intent may be formless and shadowy, it has an outcome. Secondary teachers lean heavily on the textbooks in the several disciplines, and so it may be said in fact that the chief agents in the actual determination of instructional content-and to a large extent, objectives-are the writers of manuals for the schools, who in their turn draw their materials, designs, and inspiration from the leading masters in the various fields. If this Commission can, by its analysis of the problem and constructive suggestions, induce specialists to give more attention to the larger aims, inner relations, and implications of their separate disciplines, the indirect results of its labors may be more significant than its positive confession of faith.

More often consciously planful, but sometimes less thorough in content and organization, have been the programs of objectives prepared by professional educators, makers of curricula, and the- 


\section{Framework of Programs}

orists of various nuances and bents. Implicit in all they do is some philosophy of society, some fundamental purpose in education-but frequently with little regard for the actual ends to be attained in the formation of character and the rearrangement of social situations. To the mill of opinion on the subject in hand certain leaders in history, political science, economics and sociology have brought their respective grists-the primary aims of instruction in their specialties, so far as they have ever considered this practical issue. Important committees representing national associations have added their contributions to the solution of the problem-setting forth their findings in voluminous reports. Supplementing the programs evolved by general organizations are innumerable local schemes drawn up for states, cities, and towns by committees of teachers and educational administrators. Literally hundreds of them, some thoughtful and thorough, others sketchy and superficial, are to be found in educational libraries. Finally, to crown it all, correlators and annotators have compared, analyzed, and tabulated these varied offerings and generalized 


\section{$A$ Charter for the Social Sciences}

the results in columnar forms. Therefore it is not on an uncharted sea, without headlands and lighthouses, that this Commission of exploration sets sail.

THE REQUIREMENTS OF THE TEACHING AND LEARNING PROCESS

Whatever may be the demands of scholarship and of society itself, civic instruction cannot accomplish the impossible. It is conditioned by the teaching and learning process. What kind of teachers do we have? How are they trained? How do they go about their tasks? Of necessity, therefore, this Commission must urge teachers to take stock of themselves, to work out a philosophy of personal living and thinking in relation to the difficult tasks imposed upon them by the obligations of civic instruction. Methodology alone cannot enable them to do this. They must secure for themselves a clear and realistic picture of modern society, gain insight into the central concepts of our industrial order and its culture, acquire habits of judicially examining its issue and problems, develop the power to look with 


\section{The Teaching and Learning Process}

calm and untroubled eyes upon the varieties of social pressures which bear in upon them, and nourish, by wide study, their capacity for dealing justly and courageously with current modes of living.

In their advanced studies, of course, they come in contact with wide circles of conflicting opinions and judgments; but, when they settle down in their respective communities to the routine of instruction, they usually find themselves in a conventional climate of ideas that tends to stifle independent research and the exercise of the critical judgment. Cut off from contact with the living spirit of scholarship, they tend to approximate the average, to take on the dogmas of the local mores, and to seek security in a protective timidity. School administrators, subjected even more rigorously to outside pressures, too often strengthen the constricting forces that bind the bold spirit of scientific inquiry and instruction. Evidently, then, the best-laid plans of civic instruction-instruction realistic, living, and courageous-may be turned to dust in the hands of the untrained and timid teacher. To accomplish 


\section{$A$ Charter for the Social Sciences}

results many things must be over-emphasized, for by the time they filter down through the media of instruction their weight diminishes.

When the demands of scholarship and society are heard and the teaching process is considered, there remains another fundamental bench mark to be placed as a point of reference. The whole scheme revolves around the pupils in the schools graded according to age and intelligence. It is not adults we are addressing; it is children ranging in years from five to eighteen or twenty. We must beware of generalizations that transcend their knowledge and experience, abstractions that cannot sink into immature minds. "No one sees farther into a generalization," William James reminds us, "than his own knowledge of details extends." However artistically balanced may be the controlling philosophy of a scheme of social studies, the presentation of it must be geared into youthful experience. It must proceed from concrete facts and advance by realistic stages in the direction of the ultimate goal, giving firm content to abstractions as they come into the program at the successive levels. Unless, therefore, univer- 


\section{The Supreme Purpose}

sity scholars squarely face the ultimate problems of instruction in detail and public school teachers keep their eyes on the requirements of scholarship and society as well as the learning process in youthful minds, civic instruction cannot fulfil its social mission, no matter how excellent may be its philosophy or practical devices. It is at this border realm of contact that all who are concerned with the issues before us must meet in common counsel for co-operative enterprise.

THE SUPREME PURPOSE IN CIVIC INSTRUCTION-THE CREATION OF RICH AND MANY-SIDED PERSONALITIES

Whatever may be the limitations imposed on instruction in the social studies by the requirements of scholarship and the social scene, whatever may be the problems raised by the possibilities in front of us, there remains at the center the supreme challenge put by the purpose of the public school system itself. Conceivably social science as a branch of human knowledge might conflict with or have no interest in the reasons for existence offered by the public school system, but inexorably the latter will impose on social studies 


\section{$A$ Charter for the Social Sciences}

in the classroom conditions of its own. Insofar as social science is truly scientific it is neutral; as taught in the schools it is and must be ethical; it must make choices and emphasize values with reference to commanding standards.

All instruction in the schoolroom must turn on the individual pupil; its results must inhere in the individual, even though some idealized scheme of social arrangements may be the controlling motive in the organization and imparting of learning. If society were static and all were content with whatever happens to be, then it would be possible for the schools to do effective work in preparing typical personalities for typical grooves in a fixed order. But society is changing, not static, and such a conception of education would subdue all hopes, all aspirations, without which mankind will perish, to a lock-step routine soon to be possessed by the rigor of death. Even the poorest of mortals and the meanest of societies are seldom content with their accomplishments after they pass beyond the lowest stage of primitive barbarism. This intangible is a fact, just as much as railroads, taxation, and agricultural output are facts. 


\section{The Supreme Purpose}

Given mankind capable of growth and improvement, given a changing world, with its swift technical transformations and democratic conflicts, it follows that no fixed set of dogmas and disciplines listed as articles of faith, from which it is treason to vary, can automatically prepare children for success, adaptation, and good living in the world of tomorrow, the world in which their adult years must be spent. Any one who will compare the books of civic instruction of, let us say, 1875, with the problems which a child trained in them confronted in mature years between 1890 and 1930 (allowing that span of life) can readily see that by no possible effort of mind could the teachers of 1875 have fitted the child for dealing precisely with many of the difficult issues that later perplexed him.

In modern civilization life is and must be a series of more or less difficult choices made by individuals adone or in groups, involving conduct, creative activity, ideas, loyalties, and obligations. No scheme of education can foresee all the important choices of the coming years and provide mechanically correct reactions for each situation 


\section{$A$ Charter for the Social Sciences}

in which a decision must be made. This ought to be said emphatically and definitively. It is easy to make a creed of fine words, but no person of wisdom will be deceived by it. Those who make and those who recite such a creed will differ in choices in identical situations and will place variant interpretations on it which destroy its validity as an instrument of finality. By the formulation of mere word programs no objective will be attained except a verbal recital. To be sure, certain fixed habits, such as brushing one's teeth, may be established under discipline, but their range is necessarily limited to personal conduct. In the wider range of social relations it is not words that count, but capacity to understand, analyze, bring information to bear, to choose, to resolve, and to act wisely. Competence in the individual, not dogma, is our supreme objective.

So far as the individual is concerned, perhaps all may be summarized under the head of developing latent powers. Our fundamental purpose here is the creation of rich, many-sided personalities, equipped with practical knowledge and inspired by ideals so that they can make their way 


\section{The Supreme Purpose}

and fulfil their mission in a changing society which is a part of a world complex. Such rich and many-sided personalities are informed about a wide range of affairs, both immediate and remote. They are aware of personal and social responsibilities. They know that environment can be changed within limits by individual and social action. They know (or believe) that the individual can be modified by altering his environment and stimulating his effort. They are firm of will, for without will nothing great can be accomplished. They are imbued by the highest aspirations of the human race, for without aspiration there is no great motive power for action. Those who hope for nothing, do nothing. It is true that in its inner recesses character seems to defy analysis, but broadly viewed it presents many aspects which may be developed by education. It is not possible, of course, to separate these aspects sharply nor to arrange them mathematically in order of importance; but for the convenience of consideration they may be described tentatively by reference to tangible features.

To begin at the easiest point of departure, a 


\section{$A$ Charter for the Social Sciences}

rich and many-sided personality possesses information. What and how much? No positive answer, good always and everywhere, is possible. It is the function of each branch of social science to say what are the rightest and truest fragments of knowledge which those who call themselves intelligent should possess in that discipline. It is the business of philosophy to eliminate, to give unity, perspective, and balance to these fragments, and of letters to make them vivid and human.

But this knowledge is not fixed for all time. What passed for worth-while knowledge of the Constitution or of woman's position in society fifty years ago is not appropriate for efficient use in 1932. So rapid is the advancement of learning in many fields that only highly trained specialists can do it justice in classification and emphasis. Yet, speaking summarily, we may say that the primary information which social science must supply through the schools to individuals is information concerning the conditioning elements, realities, forces, and ideas of the modern world in which life must be lived. Any representation of them is bound to be partial and out of perspective, 


\section{The Supreme Purpose}

such is the frailty of the human mind, but it must be attempted in textbooks, supplementary works, maps, motion pictures, and every possible apparatus for conveying information vividly and realistically to the immature mind.

To attain information certain skills are necessary. These are signs and instruments of power. In a way, this topic might well be the first on the list, for the information imparted in the schoolroom is severely limited in its range, and is only a small part of the equipment for life. A knowledge of how to acquire knowledge is a permanent possession which can be used throughout life. The acquisition of such knowledge can be promoted by discipline in the methods of attaining access to information-the use of encyclopedias, authorities, documents, sources, statistical collections. Even in the lower grades it is possible to awaken and stimulate this latent capacity. Any teacher can ask: How do we know the truth about this simple situation? And then answer it by reference to authoritative materials. All the way through the schools the process may be followed, ever sharpening the mind by increasing the complex- 


\section{$A$ Charter for the Social Sciences}

ity of the situations about which questions are asked and of the materials necessary to correct answers, rising steadily in the complexity and abstraction of the subjects considered.

Next to the collection of data is skill in analysis -the power to break massed data or large themes into manageable units, and to get at irreducible elements in any complex under scrutiny. More difficult, but indispensable to the attainment of skill in acquiring knowledge, is synthesis-the art of putting elements together, drawing inferences from them, comparing results with previous conclusions and preconceptions. Geared into the exercise of these skills is that of memory-a capacity, like others, which can be acquired in some degree by assiduous practice. In each branch of social science these skills can be developed in connection with the use of appropriate materials, including wherever possible the raw materials of life, as well as printed or graphic representations of it. These skills are not limited to academic operations; they are the secrets of achievement in vocations, in personal affairs, in social situations.

In the acquisition and use of knowledge, 


\section{The Supreme Purpose}

method as well as skill is essential to power. Perhaps they are aspects of the same thing. At all events, in our age emphasis is rightly laid on the scientific method. Having wrought marvelous results in the world of nature, where mass and force can be measured and manipulated, it has been imported into social studies where it also produces extraordinary results within more decided limits. Whatever its shortcomings, it is the only rational instrument which intelligence can use in reaching workable conclusions respecting large areas of life. Natural science, correctly conceived, is adventurous in seeking new knowledge, patient, impartial, and exacting-a powerful technique for discovering conditional truth. It liberates intelligence in dealing with both human and material affairs, and at the same time provides intelligence with a powerful instrument for amassing and producing knowledge. To implant it firmly in youthful minds is an obligation imposed on social science by its intrinsic nature, and by the very necessities of a fluid, technological civilization.

Habits, no less than knowledge and skill, are a 


\section{$A$ Charter for the Social Sciences}

characteristic of every rich and competent personality. They are indispensable to efficiency in private life and stability in public relations. They make for economy by reducing many efforts to the level of routine and thus releasing mind and spirit for more adventurous and creative enterprises. If habits are sometimes the symbols of servility, they are also the foundations of a higher freedom when intelligently formed. The most precious institutions for the orderly conduct of life are at bottom great collective habits established by reason and selection. Among the habits which social science is concerned with forming are personal cleanliness, industry, courtesy, promptness, accuracy, and effective co-operation in common undertakings. To some extent these habits may be encouraged by precept drawn from the data and conclusions of social science; perhaps to a greater extent, by organized experience in the classroom supplemented by community action in positive, if limited, forms. Civic instruction should not be confined to the printed page while the laboratory of life lies at hand.

Akin to habits, less dynamic but equally neces- 


\section{The Supreme Purpose}

sary to individual accomplishments and group performances, are certain elements of personality which may be described as attitudes. Under this head may be included such tendencies and propensities as respect for the rights and opinions of others, zeal for truth about many things large and small, pride in the achievement of individuals, communities, America, and mankind, admiration for heroic and disinterested deeds, faith in the power of men and women to improve themselves and their surroundings, loyalty to ideals, a vivid sense of responsibility in all relations, a lively interest in contemporary affairs, a desire to participate in the world's work, far and near. By no formulas of creed can these attitudes be automatically established, but their worth in promoting the welfare of individuals and the fortunes of the commonwealth can be readily illustrated in many phases of social science; while emphasis on these aspects of character can be easily reinforced by studies in biography which furnish pictures of individuals working in and through society.

Of all the attitudes or loyalties to be cultivated by social science, love of country, or patriotism, 


\section{$A$ Charter for the Social Sciences}

comes first on the accepted programs of civic instruction. If to some thinkers patriotic sentiments, like the instincts of a gentleman, need no advertising or promoting but may be taken for granted, it must be admitted that the educators and lawmakers of the United States do not share this view. But when their aims are closely scrutinized, marked differences of opinion appear with respect to the ideas and emotions necessary to qualify the citizen for true patriotism. They agree, of course, on certain formalities, such as flag etiquette, observance of holidays, and pledges of allegiance.

Beyond ceremonies and recitals much confusion reigns. Many seem inclined to believe that only a good Republican of the right wing, or a good Democrat of the same persuasion, deserves the appellation of patriot. Others identify patriotism with loud professions on public occasions. While social science is at war with hypocrisy and chauvinism as perils to the progressive development of the United States in the world of nations, it brings full tribute to that patriotism which is associated with heroic figures, such as Washing- 


\section{The Supreme Purpose}

ton and Lincoln, recognizing its fundamental value to the safety of American society and in the making of a great civilization.

Loyalty to America, an appreciation of its achievements, and faith in its powers are indispensable to defense against attacks from without and to the promotion of the good life within. The wise, no doubt, draw upon the wisdom of all lands and all ages for strength and inspiration, but they know that they have a geographical location and a cultural heritage. From whatever source their ideals are derived, they must work with the materials at hand. The widest universality must be brought to a focus and given expression in concrete situations; otherwise it ends in thin hopes and empty words. The loyalty which history and social science can instill is, then, the loyalty of reasoned affection, not the loyalty of tribal prejudice. "You have taken an oath of allegiance to the United States," said President Wilson to foreign-born citizens at Philadelphia in 1915. "Of allegiance to whom? Of allegiance to no one unless it be God. Certainly not of allegiance to those who temporarily represent the 
great Government. You have taken an oath of allegiance to a great idea, to a great body of principles, to a great hope of the human race." That attitude of exalted patriotism civic instruction can hold up as a prime virtue beyond challenge and can implant in the minds of children without doubts and reservations.

To information, skills, habits, and attitudes, will power and courage must be added if rich and many-sided personalities are to be nourished. They are not measurable by intelligence tests; they are elusive, though real, but they are necessary to carrying successfully the burdens of life; they are the driving elements in invention and achievement, in industry, in politics, in every department of life. Much of the exceptional work ascribed to genius may be truly assigned to resolution and daring, rather than to luck or the divine spark. Will-power and courage can often overcome other weaknesses and deficiencies and accomplish results where higher talent without their dynamic drive fails. To what extent can they be fostered by civic instruction? No exact answer is possible. But it is safe to assume that, like other 


\section{The Supreme Purpose}

faculties, they can be stimulated by the citation of notable examples from the biographical roll and by such exercises as the classroom and its collateral activities can provide. Here is a phase of social science that has been too long neglected and is in danger of being overlaid by the emphasis on information and powers of discrimination that can be formally tested.

Strangely affiliated with courage, and yet distinct from it, is imagination-the capacity to compare, contrast, to combine and to construct. It took imagination to conceive the possibilities of the Federal Union, to invent the telegraph, to devise the moving-picture machine. Everything that is added to the world's store of riches existed first in some human imagination before it was embodied in reality. This is true of social arrangements, all arts and spiritual relations, as well as of machines and material things. Although natural science and other disciplines can be employed to foster imagination, social science likewise has obligations in this connection. In tracing the rise and growth of ideas, history is dealing with the works of the imagination. What history em- 


\section{A Charter for the Social Sciences}

phasizes in broad movements, biography illuminates in detail. In economics, politics, and sociology, imagination is a dominant constructive force. All rich personalities are imaginative, and if education is concerned with the making of them, it must cherish those who can dream dreams and see visions.

Deeply rooted in imagination is another element of the full life-esthetic appreciation. Life without it is barren and barbaric, no matter how rich in material goods. It provides inspiration for arts and letters, for home planning, for city planning, for social betterment in every direction. The indictment brought against industrial civilization is not limited to poverty and unemployment, but runs against its hideous factories, its unsightly residential districts, and its depressing homes. In a large measure, the evils in this state of affairs are due to the weakness of esthetic appreciation among those who direct and labor in our planning and constructive enterprises. Engineering has demonstrated that they are not necessary, that in proper hands it can supply corrective measures; and when popular taste is sufficiently elevated, 


\section{The Supreme Purpose}

most of them will disappear. In raising the level of this taste, education in social science can be particularly effective. The history of art and letters can be brought into intimate relation with political economy. Examples of the best achievements can be described and illustrated by pictures. The rôle of esthetic appreciation in the development of other civilizations can be brought under review and the minds of pupils fired with zeal for the best and finest products of genius.

So far we have spoken of the creation of rich and many-sided personalities as the major purpose of social science in the schools and have implied at least that identical instruction in the subject will produce identical results throughout the entire student body. This implication, of course, is without warrant. Teachers of long experience know, and intelligence tests demonstrate, that there is in every class a small percentage of excellence at the top, another percentage of failure at the bottom, and a huge bulk of mediocrity in the middle. Whether or not this will always be so, whether or not any scheme of differentiation in instruction can raise the whole level, no edu- 
cational program can ignore variations in the output of pupils. The great mass of the people, rich or poor, do not invent anything, do not conceive of any new ideas, do not desire to depart far from a commonplace routine in life. Every great invention, every work of art, every beneficent reform originates in the brain of some individual-or at best a small group of individuals, and often has to make its way against popular hostility. A civilization that does not have leaders to point out new paths, to explore untried regions, sinks into stagnation. Perhaps more than any other form of government, democracy depends upon leadership to formulate, propose, advocate, dare, and direct. Hence it is one of the inescapable duties of teachers in social science to discover, draw forth, and inspire students with capacity for leadership and creative work. From this source comes the continuous renewal that gives freshness and vigor to civilization.

This point can scarcely be overemphasized. Practically all systems of civic training lay stress on conformity, discipline, regimentation. To a considerable extent they must do so to survive; 


\section{The Supreme Purpose}

but in this development there is a tendency to lose sight of the fact that the cultivation of independence in judgment among citizens is also necessary to survival. This is not merely in the interest of the individual himself; it redounds in the long run to the interest of the group. In the social world no less than in the biological world, adaptation is indispensable to success in the struggle for existence, and groups in which complete and rigid conformity has been attained are often not as strong as groups in which the faculty of criticism is cultivated and exercised. Particularly is this true in our technological age when new inventions are constantly introducing novel factors into the social scene, forcing readjustments in productive and distributive processes, and indicating lines of more efficient performance. There are times, of course, as Milton warned us long ago, when emphasis must be laid on order and conformity, and there are others when the emphasis must be shifted to liberty and independence of judgment. Recognition of this truth must find its expression in any well-rounded program of social studies.

We lay stress, therefore, on the importance of 


\section{$A$ Charter for the Social Sciences}

inventiveness and adaptability as a desirable outcome of social education. Particularly is this true in the field of government which is far more rigid and traditional than industry. The ideology which surrounds political institutions generally runs against the notion that social inventiveness is an essential quality of the good citizen. It sanctions the transmission of achievements already accomplished and attempts to stamp them as stereotypes good for all time. For example, one of our states forbids by law anyone to propose changes in the form of government, and some of our criminal syndicalism statutes, perhaps unintentionally, formerly went so far as to penalize all social inventiveness in government. And, it is strange to relate, many citizens of scientific training who recognize the folly of attempting to prescribe by law for all time the proper organization of industry, transportation, and communication are found insisting upon perfect rigidity in political institutions. For these and other reasons a program of social studies must reassert the significance of criticism and inventiveness as a potent force for progress and a condition precedent to survival. 


\section{The Supreme Purpose}

This is far from academic. A study of the trends in civic education in eight leading European countries reveals the following indications, to put them in summary form:

I. Since fundamental changes are already under way and are likely to continue in the near future at least, overemphasis on tradition must be corrected by a recognition of the need for attitudes and aptitudes of adjustment appropriate to a rapidly developing world.

2. Inasmuch as pupils go out of the schools into a pluralistic world of competing allegiances and loyalties, it is necessary to bridge the gap between narrow civic precepts and social behavior. In fact, there is in many respects a conflict between what the school says and what the home says-between the cult of the school on the one side and the cults of industry, labor, business, the farmer, the gang, and perhaps of sex, outside of the schools. Each one of these outside affiliations is a little world in itself. It has its system of social education and scheme of correct behavior. They all interlock, of course, but their individual characteristics are indubitable and the child must become acquainted 


\section{$A$ Charter for the Social Sciences}

with this pluralism if he is to deal wisely with competing allegiances and handle them effectively in practical life. There must be something in the experience of the race or American civilization which will show how to cope with these conflicting pressures intelligently. If the schools do not discuss them on a high level of rationality, then the pupils will wrestle with them on a level of chance and passion before and after they have left the classrooms. If civic education does not make clear the demands of these loyalties, if it fosters in children little save the spirit of conformity, they will not be fortified with the knowledge necessary to make wise choices and the strength of character required to carry them into effect.

In dealing with this question of character, we cannot overlook the necessity of co-ordinating our knowledge of the whole constitution of man both physical and mental with plans for the development of personality and types of behavior. The civic attitudes and conduct of children are not all determined by what they hear in the classes. Antisocial behavior and incapacity to learn may be due 


\section{The Supreme Purpose}

to bad teeth, physical defects, or undernourishment. In this relation the findings of physicians, psychiatrists, and psychologists must be taken into account. They may prescribe physical readjustments, food, and mental analysis of individuals. In social behavior children are not to be graded according to the calendar. While the teacher of civics may be treating a group of fifty students as if they were all alike and as if the common instruction must produce identical results, the bestlaid plans may be entirely upset in the case of many individuals on account of physical and mental variations and maladjustments. Rebellion and delinquency based on physical and mental diffculties-as well as on higher intellectual dissentmay upset the fair pageant of civic instruction. These realities must be brought into the reckoning. It is not easy to say how the problems raised by them are to be solved, but the advice and aid of the psychologist and physician must be called into service and their findings must in some way be incorporated into our thinking about instruction in the social studies.

From the spirit of all that goes before, it fol- 


\section{$A$ Charter for the Social Sciences}

lows that last words must be spoken in tones of contrition. Although social science speaks with a certain authoritative air about objectives to be attained through civic instruction, there is none of Sinai's thunder in its affirmations. Recording long lists of human errors, it conserves a saving sense of fallibility. When ideas are expressed as clearly and sharply as possible, there remains room in concrete cases for a wide variety of interpretations and choices. No scheme of instruction can vividly portray to pupils all the coming situations of their lives in which they must make fateful decisions. Nor is it possible so to objectify ideas institutionally as to eliminate the hazards of selection and rejection. Hence the inevitable necessity for laying emphasis on freedom of opinion and the liberation of intelligence as schemes of thought, affection, and practice.

This is not academic. Our state and federal constitutions, wrought out of deep experience, guarantee freedom of press, speech, and religion. This liberty is a good in itself and it permits the formulation of new standards and habits to meet perplexing situations. But the laws which 


\section{The Supreme Purpose}

proclaim liberty do not assure it. As Alexander Hamilton put the matter: "Whatever fine declarations may be inserted in any constitution respecting it, [liberty] must altogether depend upon public opinion and on the general spirit of the people and of the government." To contribute powerfully to the making of this opinion and this spirit is an undoubted task of civic instruction in the schools. 


\section{Commission on Direction}

A. C. KREY, Chairman; Professor of History, University of Minnesota.

Frank W. Ballou, Superintendent of Schools, Washington, D. C.

Charles A. Beard, formerly Professor of Politics, Columbia University; author of many books in the fields of history and politics.

Isaiah Bowman, Director, American Geographic Society of New York; President of the International Geographical Union.

Ada Сомsтock, President of Radcliffe College.

George S. Counts, Professor of Education, Teachers College, Columbia University.

Avery O. Craven, Professor of History, University of Chicago.

Edmund E. Day, formerly Dean of School of Business Administration, University of Michigan; now Director of Social Sciences, Rockefeller Foundation.

Guy Stanton Ford, Professor of History, University of Minnesota.

Carleton J. H. Hayes, Professor of History, Columbia University.

ERNest HoRn, Professor of Education, University of Iowa.

Henry Johnson, Professor of History, Teachers College, Columbia University.

Leon C. Marshall, Institute for the Study of Law, Johns Hopkins University.

Charles E. Merriam, Professor of Political Science, University of Chicago.

Jesse H. Newlon, Professor of Education, Teachers College, Columbia University; Director of Lincoln Experimental School.

Jesse F. Steiner, Professor of Sociology, Grinnell College. 


\section{INDEX}

Adams, Henry, 83

Agriculture, 39

Anthropology, 18

Appreciation, esthetic, I08

Arts, 80

Bismarck, 12

Calhoun, John C., 25

Carlyle, 12

Citizenship, $37 \mathrm{f}$.

City planning, 33

Civics, 48,76

Climate of American Ideas, $52 \mathrm{f}$.

Constitution of United States, 15 , $30,58,85,86,87,98$

Democracy, problems of, $45 \mathrm{f}$.

Economics, 17, 76

Emerson, 57, 74

Esthetics, 18, 75

Ethics, 18,82

Family, American, 29

Garrison, William Lloyd, 25

Geography, 18

Government, 35

Health, 82; public, $58 \mathrm{f}$.

Hegel's Philosophy of History, 16

History, $18,27,42$ f.; crises of, 10

Holmes, Oliver Wendell, 4I

Holmes, Mr. Justice Oliver Wendell, 85

Hoover, President, 34

Humane habits, 82
Ideal state, 54

Imagination, 107

Impulses, ethical, 72

Individual, the, $94 \mathrm{f}$.

Industrialism, $30 \mathrm{f}$.

Insurance, 79

James, William, 2, 20

Kellogg Pact, 49, 5 I

Labor, $62 \mathrm{f}$.

Law, framework of, $8 \mathrm{r}$ f.

Leisure, $63 \mathrm{f}$.

Literature, I4, 18

Marx's Das Kapital, I5

Medicine, 80

Metaphysics, 20

Milton, II I

More's Utopia, 15

Morley, John, Io, 78

National planning, 79

Opportunity, equality of, $68 \mathrm{f}$., 80

Parks, 8o

Parties, political, 36

Philosophy, 20

Planning, city and state, 80

Plato's Republic, 15

Privileges, special, 66

Psychology, I8

Ranke's History of the Popes, 14

Relations, international, 5I, 8I

Religion, 82

Requirements of teaching and learning process, $90 \mathrm{f}$. 


\section{Index}

Requirements set by social realities, $21 \mathrm{f}$.

Revolution, French, I0, 54

Rodin, 8

Roosevelt, President, 65

Rousseau's Social Contract, 15

Safety, 82

Scholarship, 2, 4, I I, 92

Science, 7, 23, IOI

Smith's, Adam, Wealth of $\mathrm{Na}$ tions, I 4

Social disciplines, nature of, $13 \mathrm{f}$. Society, requirements of, 3
Sociology, 18

Spengler's Decline of the West, I 6

Supreme purpose in civic instruction, $93 \mathrm{f}$.

Transportation, 79

Treitschke's Politics, 15

Unemployment, 67

Universal education, 79

Welfare, economic, 6I

Wilson, President, I05 
The exact titles of the various reports of this Commission cannot yet be definitely announced. The following is a list of the subject matter of the reports and the tentative titles as nearly as these can be determined at the time of this announcement:

I. A Charter for the Social Sciences in the Schools. Charles A. Beard, formerly Professor of Politics, Columbia University.

2. Some Chapters from the History of the Teaching of the Social Studies. Henry Johnson, Professor of History, Teachers College, Columbia University.

3. Citizens' Organizations and the Civic Training of Youth. Bessie Louise Pierce, Associate Professor of American History, University of Chicago.

4. The Pupil's Approach to the Understanding of Society.

5. Services of Geography to the Social Sciences. Isaiah Bowman, Director, American Geographic Society of New York, with special studies by Rose Clark of Nebraska Wesleyan University, Edith Parker, University of Chicago, and R. D. Calkins, Central State Teachers College, Michigan.

6. Education in an Industrial Age. George S. Counts, Professor of Education, Teachers College, Columbia University.

7. Study of the Organization of Content in the Social Studies Program. Rolla M. Tryon, Professor of the Teaching of History, University of Chicago.

8. Study of the Methods of Instruction. Ernest Horn, Professor of Education, University of Iowa.

9. The Problem of Training for Citizenship. Charles E. Merriam, Professor of Political Science, University of Chicago. 
10. The School Administrator's Place in the Social Studies Program. Jesse H. Newlon, Director, Lincoln School, Teachers College, Columbia University.

II. The Selection and Training of the Teacher. William C. Bagley, Professor of Education, Teachers College, Columbia University.

12. Recommendations of the Commission. This volume will contain a complete program and course of study for the social studies courses in public schools throughout the United States.

Other volumes or reports have been projected, dealing with the history of the social ideas of American educational leaders and with the problem of freedom of teaching or the growth of tolerance in the teaching of these subjects.

It is also planned to publish a number of miscellaneous studies, many of them of an exploratory character, which have been made for the committee in one connection or another.

To be published by Charles Scribner's Sons. 





\section{DATE DUE}

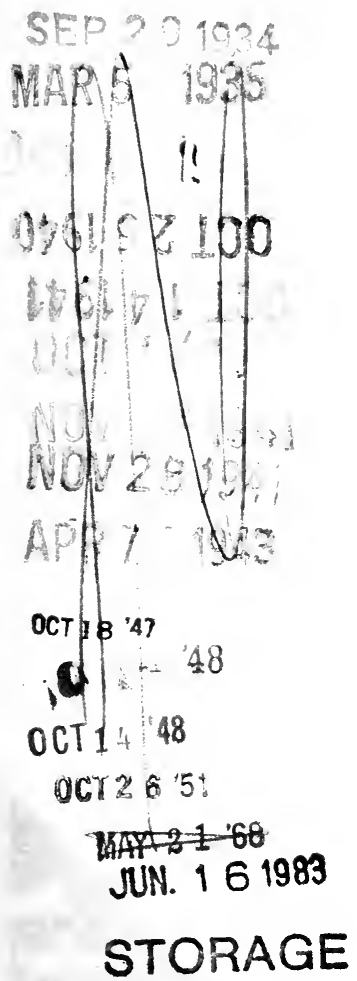


年

$\begin{array}{llll}35132 & 00340 & 5024\end{array}$

University of the Pacific Library

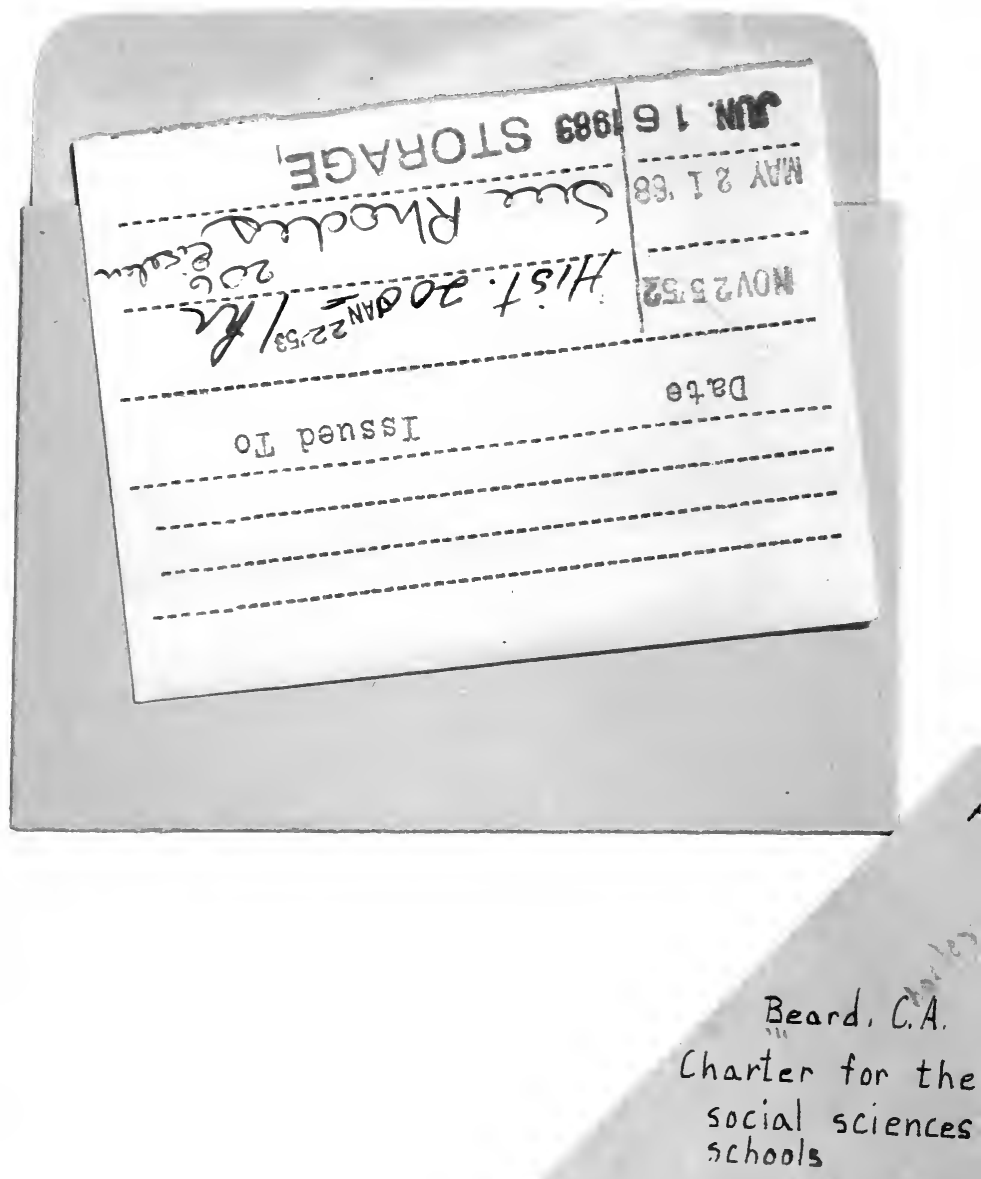


15.

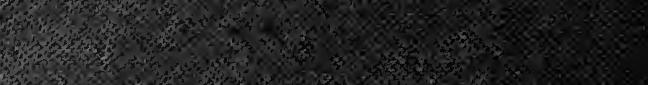

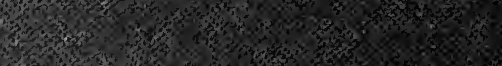

3. 1.5.

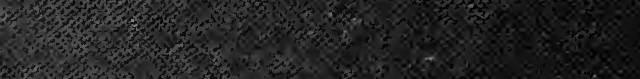

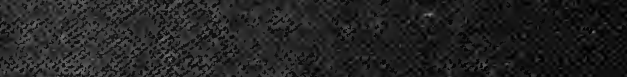
4023 and 